\title{
EL PROCESO PENAL DE TENDENCIA ACUSATORIA: ENTRE LA INOPERANCIA Y EL REFORMISMO.
}

\author{
FERNANDO VELÁSQUEZ V.'
}

\section{Resumen:}

Pese a que la Ley 906 de 2004 nació a la vida jurídica con la finalidad de implantar un sistema procesal penal acusatorio pletórico de garantías, esto es, de partes, fincado en el principio de libertad, en la presunción de inocencia, la igualdad de armas, la separación de funciones entre investigación y juzgamiento, etc. la verdad es que esa normativa, luego de múltiples reformas y declaratorias de inexequibilidad, se ha quedado en el papel y el diseño imperante es tan inquisitivo o más que el anterior; es más, la impunidad, la congestión judicial, el escrituralismo, la falta de recursos, la improvisación, la politización, la corrupción, etc., continúan. Ello demuestra, entonces, que el problema de la administración de justicia penal no es solo de leyes, sino que la crisis existente pasa por otros fenómenos que deben ser examinados de forma cuidadosa para, a partir de allí, emprender nuevos caminos. A eso invita la presente reflexión.

\section{Palabras clave:}

Código de Procedimiento Penal, crisis, inoperancia, reforma, sistema acusatorio, sistema inquisitivo.

\section{Abstract:}

Despite the fact that the Law 906 of 2004 was created in order to implement a full criminal prosecution system of guarantees, that is, of

$1 \quad$ Profesor de la Universidad Sergio Arboleda. Bogotá, Colombia. fernando. velasquez@usa.edu.co. Ponencia presentada en la "Jornadas de reflexión y propuesta sobre prioridades de reforma a la justicia" - EDUCACIÓN, FORMACIÓN DE ABOGADOS, JUECES Y ÉTICA, viernes 31 de agosto de 2018, de 8:30-12:30 a.m. 
parties, based on the principle of freedom, on the presumption of innocence, equality of arms, the separation of functions between investigation and judgment, among others. However, the truth is that these regulations, after multiple reforms and declarations of non-enforceability, have not had any real repercussion, and the prevailing design is as inquisitive or more than the previous one; Furthermore, impunity, judicial congestion, scripturalism, lack of resources, improvisation, politicization, corruption, to name a few, continue. This shows that the origin of the crisis in the administration of criminal justice is not only because of the existing laws, but also because of other phenomena that must be carefully examined in order to start new paths from there. This is what the present work invites to reflect on.

\section{Key words:}

Code of Criminal Procedure, crisis, ineffectiveness, reform, accusatory system, inquisitorial system.

\section{Introducción.}

El Código de Procedimiento Penal fue expedido hace poco más de catorce años (2004, Ley 906) y fue impuesto al compás de las exigencias del llamado "Plan Colombia" y sin que fuese producto del libre debate de ideas por parte de la academia nacional en estas materias ${ }^{2}$ así sea evidente que se haya instalado una Comisión Redactora Institucional que sesionó hasta concebir un proyecto inicial ${ }^{3}$ con la finalidad declarada de introducir un sistema procesal penal de investigación y juzgamiento de carácter acusatorio, que se anunció por el Fiscal General de entonces como con "mucha democracia y mucha garantía"; es más, se dijo que era más económico, ágil, eficiente y hasta ecológico que el anterior: "la justicia hoy es muy costosa porque es lenta, demorada, ineficiente, escrituraria, antiecológica. Estamos haciendo el mejor negocio que ha descubierto el

2 VELÁSQUEZ, F.: "Colombia: hacia un derecho penal expansionista". En: Revista Berbiquí, N. ${ }^{\circ}$ 29, Colegio de Jueces y Fiscales de Antioquia, Medellín, 2005. Pág. 5 y ss.; en contra, POVEDA et al.: Balance diez años de funcionamiento del Sistema Penal Acusatorio en Colombia (2004 - 2014). Análisis de su funcionamiento y propuestas para su mejoramiento. USAID, Bogotá, 2015. Pág. 283. Para la cual se produjo "un intenso debate académico iniciado en los años noventa del siglo pasado".

3 Véase, OSORIO, L. C. y MORALES, G.: Proceso penal acusatorio. Ensayos y Actas. Ediciones Jurídicas Gustavo Ibáñez, Bogotá, 2004. 
Estado, invertir en un aparato que está siendo costoso, por uno que sea eficiente y ágil". ${ }^{4}$

Para ello, se hizo un gigantesco esfuerzo económico y humano encaminado a construir salas de audiencias, dotar de recursos informáticos a los despachos judiciales, capacitar a jueces y fiscales, fortalecer a la policía judicial, etc.; es más, como parte del programa reformador, se desplegaron múltiples herramientas destinadas a crear conciencia entre los diversos estamentos académicos en torno a la importancia de introyectar esta transformación llamada a cambiar la cultura inquisitiva por la acusatoria, con el argumento de que era necesaria para fortalecer la democracia, mostrar mayor eficacia en el sistema adoptado, propender por la libertad de los asociados y luchar contra la criminalidad. ${ }^{5}$

Sin embargo, transcurridos más de catorce años el balance en torno a los rendimientos del modelo propulsado es desalentador porque la justicia penal sigue postrada, es inoperante e ineficiente, cosa que también sucede con toda la administración de justicia en general que es víctima de una crisis de proporciones. Y ello, recuérdese, se produce en el contexto más general de un Estado plagado de injusticia, desigualdad, discriminación, violencia y corrupción, con la consiguiente violación de los más elementales derechos humanos, en el cual se pretende hablar de estas problemáticas en forma aislada y como si en él no sucediese nada, lo cual indica que a los detentores de poder no les interesan innovaciones en ningún plano: social, económico o político, porque parecen estar contentos con el statu quo.

Esto es, pareciera que no importa la verdadera construcción de un Estado en todos los rincones del territorio nacional para que, a la sombra de la fortaleza institucional, advenga también una administración de justicia penal fuerte, democrática y al alcance de todos los ciudadanos a quienes se les tiene que garantizar su efectivo acceso a la misma, para lo cual debe existir una adecuada tutela judicial estatal que vaya de la mano de un enfoque integral, que ponga su mira en programas de trabajo social, los estudios de psicología, antropología y otras ramas de las ciencias sociales, "con el fin de atender a las personas con mayores limitaciones

4 ARANGO, B. M., PALACIO, J. G. y RIVERA, M. C.: “Justicia: de años a meses". En: El Colombiano, 2004, 13 de junio. Arango, Palacio y Rivera, 2004. Pág. 8 A.

$5 \quad$ VÉLEZ, L. G.: Otra cara del sistema acusatorio colombiano: Menosprecio de la libertad personal y autoritarismo penal. Imprenta Universidad de Antioquia, Medellín, 2012. Págs. 35 y ss.; CEJ, 2011, p. 9. 
para acceder a la justicia". ${ }^{6}$ Ello, sin olvidar que ese derecho fundamental está profundamente vinculado con el control del debido proceso y la igualdad y cobija a todas las personas, ${ }^{7}$ en especial cuando se trata de las mujeres víctimas de ciertos delitos cuya posibilidad de ser escuchadas por la justicia sufre limitaciones adicionales; ${ }^{8}$ no buscar esas metas es dejar el conflicto penal en manos de los medios de comunicación masiva o, lo que es peor aún, en poder de bandas criminales y grupos armados, siempre prestos a aplicar diversas formas de "justicia" privada, porque, como se ha expresado, en esos casos (...) el acceso a la justicia, en el país se logra a través de negociaciones y de prácticas clientelistas que desdicen de un Estado de derecho, pues prima la relación de favores sobre el principio de universalidad y la fuga del litigio hacia mecanismos-alternos como la justicia que imparten las organizaciones criminales, por lo que se hace necesario reformas que se enfoquen no sólo en una política integral de acceso a la justicia sino que incluyan políticas sociales. ${ }^{9}$

Así las cosas, a título de problema de investigación, esta exposición se pregunta si los males que aquejan a la justicia penal en el país se resuelven cambiando otra vez la ley procesal o si, por el contrario, urgen reformas de más hondo calado que ayuden a producir la necesaria transformación en otros planos; con tales miras, a continuación, se indagan las causas más salientes que explican la inoperancia del sistema judicial en materia penal y, al final, se señalan algunas conclusiones para el debate. También, se consignan las fuentes tenidas en cuenta para esta incursión académica.

\section{Las razones de la inoperancia del modelo acogido}

Son múltiples las causas que explican la postración del diseño procesal penal adoptado y que, para un mejor entendimiento, se pueden agrupar de la siguiente manera sin que ello signifique el agotamiento de todas ellas ni la completa exposición sobre la materia.

6 SÁNCHEZ, J. L.: "La reforma judicial y la búsqueda del acceso a la justicia en Colombia". En: Ratio Juris Vol. 10 N. ${ }^{\circ} 21$, 2015. Págs. 223-224.

7 MORENO, L. J.: Acceso a la justicia. Academia Colombiana de Jurisprudencia, Bogotá, 2000. Págs. 103, 108 y 186.

8 LA ROTA, M. E. y SANTA, S.: Acceso a la justicia de las mujeres. Justicia ordinaria. De Justicia, Bogotá, 2012. Págs. 5 y ss.

9 SÁNCHEZ, ob. cit. Pág. 235. 


\section{La improvisación, la falta de voluntad política y los múltiples cam- bios normativos.}

Podría decirse que la nota predominante con ocasión del proceso reformador observado durante los últimos años, ha sido la llaneza con la cual se ha manejado el mismo como se constata al mirar la planeación general y la ejecución de ese proyecto; por ello, es evidente la falta de gerencia y la improvisación que recorre la actividad de todo el aparato penal en los diversos planos, lo cual es producto de la ausencia de una política criminal clara y coherente llamada a jalonar las anunciadas transformaciones y a la cabeza de la cual debieran estar las autoridades gubernamentales y judiciales encargadas de esas tareas.

Es más, el llamado sistema penal acusatorio no ha podido ser llevado a la realidad porque se echa de menos una verdadera voluntad política de hacerlo pese a que desde su introducción se dijo, con toda claridad, que ese era uno de sus pilares esenciales, ${ }^{10}$ en otras palabras, los servidores públicos que tenían la obligación de implantarlo se desentendieron de sus tareas para dedicarse al protagonismo mediático o a hacer populismo, cuando era evidente que una empresa reformadora como la emprendida necesitaba de una dirección ajena a los compromisos partidarios y pensada para llevar a la realidad el mismo durante por lo menos dos décadas, mediante un trabajo planificado y persistente. Aquí, por el contrario, los encargados de la tarea se dedicaron a hacer demagogia barata y a desfilar por los medios de comunicación masiva; por eso, pues, la introducción de la cultura acusatoria se quedó en el papel.

Y ello, por supuesto, se constata cuando se examina la normatividad original que ha sido objeto de múltiples cambios (unos veinte en total, que se suman a los 68 cambios observados en la legislación penal sustantiva) casi siempre inesperados y coyunturales, la mayoría de las cuales ha contribuido a desvertebrar el modelo original (Ley 906, 2004) porque no atienden a un diseño intelectual previo ni responden a unas determinadas directrices en estas materias; $;{ }^{11}$ incluso, lo mismo sucede con los proyectos de reforma a la justicia concebidos durante las últimas legislaturas que decepcionan desde su primera lectura, porque no contienen ninguna promesa de transformarla de manera seria e integral y apenas sí se adivinan algunas primicias muy puntuales, que poco o nada inciden en las transformaciones legislativas

10 PEDRAZA, M. A.: “Constitución política y sistema penal acusatorio". En: Revista del Instituto Colombiano de Derecho Procesal, Vol. 31 N. ${ }^{\circ}$ 31, 2005. Pág. 152.

11 POVEDA, ob.cit.. Págs. 287, 289 
requeridas. Por supuesto, lo que demuestran esas propuestas o reformas es que con ellas los legisladores de turno dicen querer dotar de más "eficiencia" al modelo adoptado pero, en realidad, lo que hacen es desvirtuar "de forma constante sus principios político-criminales". ${ }^{12}$

Adicional a ello, esas inconsultas transformaciones legislativas terminan por desestabilizar el propio cuerpo jurisprudencial construido en torno al derecho positivo impidiendo unos mejores desarrollos:

Tanta reforma hace muy difícil que las decisiones judiciales de los altos tribunales puedan formar una jurisprudencia coherente, y mucho menos que esta pueda aquilatarse, puesto que la vigencia en los últimos catorce años de tres códigos hace imposible forjar un pensamiento sereno, reposado y tranquilo sobre las grandes cuestiones procesales penales que la nación necesita resolver, aislada y objetivamente consideradas por quienes tienen que decidirlas motivada y fundadamente, para así poder sentenciar lo que más convenga al desarrollo jurídico del país, sin perjuicio que si de paso se resuelve también el problema jurídico que se plantea en el caso concreto, se colme satisfactoriamente toda aspiración sobre el enorme alcance del valor Justicia conseguido por la propia jurisprudencia. ${ }^{13}$

De allí, que esas mutaciones normativas solo terminen por ser verdaderas expresiones del populismo punitivo, ${ }^{14}$ esto es, meros saludos a la bandera para hacerle creer al conglomerado que algo se hace así sus promotores sepan de antemano que ese ejercicio no conduce a nada; es más, la lectura de las mismas deja casi siempre la amarga sensación de que, en el fondo, no se quiere tocar a los estamentos judiciales actuales y a sus "carteles de la toga" y antes, por el contrario, se busca es fortalecerlos, porque solo se impulsan reformas de papel para tener cautivo al conglomerado alimentado con mucho circo y poco pan. Por eso, ha hecho carrera acudir a las modificaciones de los textos legales cada que se produce un cambio político, se elige un nuevo funcionario de alto rango, o se comete un crimen que conmueve a la opinión pública a la cual se manipula con antelación a través de los periódicos y las revistas, la radio y la televisión, que son

12 BAYONA. D. M. et al.: "Diagnóstico del sistema penal acusatorio en Colombia". En: Acta Sociológica, N. ${ }^{\circ} 72$, enero-abril, 2017. Pág. 74.

13 GÓMEZ, J. L.: Los Fundamentos del sistema adversarial de enjuiciamiento criminal (Fortalezas y debilidades del Proceso Penal Acusatorio con Juicio Oral y Público. Su interpretación en América Latina, con especial referencia a Colombia). Ediciones Jurídicas Andrés Morales, Bogotá, 2015. Pág. 375. 
hoy los medios a través de los cuales ella se expresa; ${ }^{15}$ y esos cambios, adviértase, casi siempre se producen para sacrificar las garantías y los derechos ciudadanos pues ellos son los que más réditos producen a quienes utilizan el proceso legislativo con un trofeo electoral.

\section{Otra estafa de etiquetas.}

A más de lo anterior, pese a afirmarse de forma reiterada que la transformación normativa llevada a cabo en 2004 implicaba el paso de un autoritario modelo inquisitivo de investigación y juzgamiento en materia penal, que había predominado a lo largo de quinientos años, a uno liberal acusatorio, de partes, eficiente, con separación de las funciones de investigación y funcionamiento, oral ${ }^{16}$ y no escritural, apto para luchar contra la criminalidad organizada, defensor de las víctimas, propio de un programa de justicia restaurativa, idóneo para mejorar la calidad de las decisiones judiciales y restaurar la confianza de la ciudadanía en el sistema penal y, en fin, tejido por una red de principios garantistas, ${ }^{17}$ la verdad es que esa aseveración se quedó en el papel porque en la práctica el sistema imperante es más inquisitivo, déspota, y tan escritural como el anterior, sin que por ninguna parte se vean caminar las ansiadas garantías consagradas en el título preliminar del Código e introducidas en el programa penal de la Constitución, porque ellas son sistemáticamente irrespetadas en medio de un autoritarismo muy marcado que también arrasa con el derecho de defensa convirtiendo a los abogados en ejercicio en meros estorbos. ${ }^{18}$ Los principios proclamados, pues, son solo la fachada para encubrir un sistema procesal penal que - de espaldas al diseño constitucional-abandera el terrorismo punitivo y que, para acabar de ajustar, carece de recursos suficientes para poner en marcha semejante programa legislativo. ${ }^{19}$

15 FERRAJOLI, L.: Principia iuris. Teoría del derecho y de la democracia. 1. Teoría del Derecho, trad. P. Andrés Ibáñez et al. Trotta, Madrid, 2011. Pág. 799.

16 Nota que saludó con ahínco la doctrina: SERJE, C. H.: "Cosmovisión actual de la oralidad en el sistema penal acusatorio desde la perspectiva de la Teoría de la comunicación". En: Cuadernos de Derecho Penal N. ${ }^{\circ}$ 5, 2011. Págs. 65 y ss.

17 CEJ, 2011. Págs. 17 y ss.; AVELLA, P. O.: Estructura del Proceso Penal Acusatorio. Imprenta Nacional, Bogotá, 2007. Págs. 29 y ss.; SOLÓRZANO, C. R.: Sistema acusatorio y Técnicas del Juicio Oral. Ediciones Nueva Jurídica, Bogotá, 2008. Págs. 65 y ss. 18 La CEJ, en atención a lo dicho por Poveda et al., ob. cit. Pág. 287. Trata de "dorar la píldora" cuando dice que para el año 2014 "el Balance en materia de garantismo de los derechos de los procesados es agridulce".

19 VELÁSQUEZ, F. Presentación. F. Velásquez: Sistema Penal Acusatorio y nuevos retos. Universidad Sergio Arboleda, Bogotá, 2010a). Pág. 7. 
Así las cosas, pese a las aseveraciones escuchadas en el sentido de que ese patrón procesal tiene las notas propias del modelo acusatorio ello no es así porque el país no ha incorporado de verdad el sistema adversarial y, en instituciones claves, "está de hecho muy alejado de él", ${ }^{20}$ por eso, quienes han defendido esta innovación y ayudaron a introducirla, hoy llaman la atención sobre las lagunas y los vacíos observados: "El mito de contar con un sistema acusatorio «a la colombiana» ha dejado al proceso penal patrio convertido en una criatura que parece remedar la organización judicial de nuestro país: está llena de cabezas, pero débil de miembros". ${ }^{21}$ Es más, indican que "pulula un enorme riesgo de reconstrucción de la tendencia inquisitiva del anterior sistema" 22 como producto de la "falta de gerencia del caso y de la cultura del pasado", cuando no de los aplazamientos que se constituyen en la enfermedad terminal del modelo acogido, sin olvidar los vientos de contrarreforma que suelen soplar de forma periódica y, casi siempre, presididos de un autoritarismo rampante.

De esta forma, el cliché de "acusatorio" colgado a ese modelo es apenas un adjetivo que se predica del nombre o sustantivo "sistema" mediante el cual se encubre un patrón por completo inquisitivo (algunos prefieren llamarlo un "híbrido" ${ }^{23}$ que propende por la introducción de los criterios de oportunidad con la consiguiente privatización de la justicia penal, de tal manera que tienden de nuevo a obtener confesiones y a no realizar el juicio oral, concentrado y público del que tanto se habla, todo ello bajo la égida de dos pilares de los sistemas inquisitivos: secreto más confesión para la obtención de la verdad. ${ }^{24}$ En otras palabras: el pomposo modelo acogido llamado como "sistema penal acusatorio", hoy no es ni "sistema" ni "acusatorio", máxime si se juega con las designaciones "inquisitivo" y "acusatorio" como si no fuera evidente que son solo categorías que sirven para expresar por lo menos seis niveles o sentidos conceptuales distintos. ${ }^{25}$

20 GÓMEZ, ob. cit. Pág. 397.

21 MUÑOZ, O.: Las Raices Angloamericanas del Sistema Procesal Penal Acusatorio. Universidad Sergio Arboleda-Editorial Jurídica Andrés Morales, Bogotá, 2018. Pág. 349.

22 Ibídem. Pág. 351.

23 BAYONA et al., ob. cit. Pág. 74.

24 ANITUA, G. I.: "La importación de mecanismos consensuales del proceso estadunidense, en las reformas procesales latinoamericanas". En: Revista Brasileira de Direito Processual Penal, Porto Alegre, Vol. 1, No. 1, 2015. Anitua, 201. Pág. 55.

25 LANGER, M.: "La dicotomía acusatorio-inquisitivo y la importación de mecanismos procesales de la tradición jurídica anglosajona. Algunas reflexiones a partir del procedimiento abreviado". En: J. B. J. Maier y A. Bovino (Comps.): El procedimiento abreviado. Editores del Puerto, Buenos Aires, 2001.Pág. 102. 
Es más, se olvida que no existen propiamente "dos modelos" puros, sino que, en los diversos ordenamientos, se observan mezclas o calcos de los patrones identificados, ${ }^{26}$ al punto de que deben "abandonarse los vanos intentos de expresar el meollo del contraste entre la administración de justicia angloamericana y continental mediante la yuxtaposición de esos conceptos", ${ }^{27}$ porque lo importante no es esa distinción sino como se inserta el aparato judicial en la estructura y en la ideología del Estado. ${ }^{28}$

Así las cosas, cabe concluir, el diseño contenido en la ley 906 de 2004 se presente con una cara dual: una, en apariencia liberal y garantista; y, otra, inquisitiva y autoritaria:

(...) una que podríamos llamar declarada, que planteaba que en Colombia se había diseñado un proceso penal que garantizaba los derechos de los justiciables tras la consagración de un juicio público, oral, contradictorio, concentrado y con inmediación de la prueba por parte del juez, y la otra, que llamaríamos no declarada, que enseñaba que el propósito de la reforma procesal era conseguir que los justiciables renunciaran al debido proceso y en su lugar acogieran el subsistema de justicia negocial, de tal suerte que la condena se impusiera sin las fatigas de un juicio previo. ${ }^{29}$

\section{La cooptación del sistema por la corrupción galopante.}

Así mismo, es indudable que la corrupción cada día más creciente también permea y debilita el modelo introducido e impide su crecimiento y fortalecimiento, pues ella afecta todas las funciones que tiene a su cargo el sistema judicial, para el caso en materia penal: jurisdiccionales, de apoyo a la labor jurisdiccional, de gerencia de la rama, de gobierno de esta, y asociadas a la nominación o designación de servidores públicos; ${ }^{30}$ no se olvide, entonces, que la corrupción es un fenómeno que forma parte de la vida social (política y económica) y ella no se puede entender al margen

26 DAMASKA, M. R.: The faces of Justice and State Authority. Yale University Press, New Haven-London, 1986. Págs. 1 y ss., 241-242.

27 DAMASKA, M. R.: Las caras de la Justicia y el poder del Estado. Análisis comparado del proceso legal. Editorial Jurídica de Chile, Santiago de Chile, 2000. Pág. 17.

28 VERVAELE, J. A. E.: "Bases para la armonización internacional Del proceso penal acusatorio. F. Velásquez: Sistema Penal Acusatorio y nuevos retos”. Universidad Sergio Arboleda, Bogotá, 2010. Pág. 63.

29 VÉLEZ, ob.cit. Pág.27.

30 VILLADIEGO, C. y HERNÁNDEZ, J. C.: “Aproximación al análisis de la corrupción en la rama judicial colombiana”. En: L. Villar y D. Álvarez (Eds.): Lucha integral contra la corrupción en Colombia: reflexiones y propuestas. Fedesarrollo, Bogotá, 2018. Pág. 342. 
de la evolución del Estado, donde la administración de justicia encuentra también su cobijo. ${ }^{31}$ El fenómeno es tan grave y de tales proporciones, que ya no hay semana en la cual no se anuncie la captura de servidores de la justicia penal envueltos en típicos delitos de funcionarios o en hechos de corrupción grosera, todo ello con el consiguiente deterioro de la imagen de la administración de justicia penal; de allí que, según datos de la propia Fiscalía General de la Nación, "entre el 2008 y el 2016 se registraron 6475 noticias criminales por hechos delictivos asociados con corrupción, en los que al menos un indiciado era juez, fiscal, magistrado o empleado judicial". ${ }^{32}$ Es más, para mostrar la permanencia del fenómeno unido a la congestión judicial, la Corporación Excelencia en la Justicia en su balance de los primeros diez años de vigencia del sistema dice que "la congestión y la corrupción han sido asuntos permanentes en esta década". ${ }^{33}$ Incluso, como muestra de la descomposición reinante se empiezan a generalizar los llamados "carteles de la toga" que envuelven a organismos $\mathrm{y}$ corporaciones encargados del servicio, cuyos integrantes (jueces, magistrados, funcionarios de apoyo, abogados en ejercicio, policía judicial, etc.) negocian de forma abierta y tosca con las decisiones judiciales, sea que se las vendan a los medios de comunicación o a los interesados; a este respecto, recuérdese, se ha llegado a tales extremos que para asombro de todos un integrante de una de esas organizaciones delictivas llegó en 2016 (aunque fue el fiscal anterior quien lo vinculó a ese ente) a ser el director de la Unidad Anticorrupción de la Fiscalía General de la Nación y ese hecho, que en cualquier país civilizado le hubiera costado su vinculación y el escarnio público a quien promovió a dicha persona para tan importante cargo, no le pasó ninguna cuenta de cobro al actual Fiscal General de la Nación quien siguió impertérrito en el ejercicio del mismo, como si no hubiese pasado nada. Ese malhadado funcionario fue condenado aquí y luego extraditado a los Estados Unidos donde también se declaró culpable (El Espectador, 2018, mayo 19).

Otro ejemplo bien doloroso, sucedido al interior de la misma Fiscalía, es el protagonizado por la administración que rigió los destinos de ese ente entre 2012 y 2016 que se gastó 214.400 millones de pesos en una

31 VELÁSQUEZ, F.: "Corrupción y política criminal”. En: L. Greco y A. Martins: Direito penal como critica da pena. Estudos em homenagem a Juarez Tavares por seu $70^{\circ}$ aniversário em 2 de setembro de 2012. Marcial Pons Ediciones Jurídicas y Sociales, MadridBarcelona-Buenos Aires-São Paulo, 2012. Pág. 690.

32 VILLADIEGO Y HERNÁNDEZ, ob.cit. Pág. 342.

33 POVEDA et al., ob. cit. Pág. 184. 
escandalosa feria de contratos de la cual se beneficiaron 419 personas (exmagistrados, políticos, abogados, periodistas, etc., cercanos al Fiscal General de la época) entre el primero de enero de 2014 y el 17 de septiembre de 2015 (Semana, 2015, diciembre 9; Lewin, 2015) y, agréguese, en la construcción de una pretensa universidad cuyos edificios hoy devora la maleza; este capítulo, pues, toca con la corrupción presupuestal y en materia de contratación por parte de ese ente que, hasta ahora, permanece en la más absoluta impunidad.

Incluso, y ello también es una forma de corrupción, la justicia penal se resiente por la presencia del fenómeno conocido desde hace décadas como el clientelismo, ${ }^{34}$ esto es, se hace referencia a una práctica en cuya virtud se instala un sistema político elitista con la consiguiente debilidad del Estado, tanto que los estudiosos hablan de "una amistad por interés entre desiguales, el cual parte de reconocerse como una forma de vida y una concepción de la sociedad". ${ }^{35}$ Así las cosas, este tipo de reflexiones hace recordar que la corrupción judicial no solo debe ser analizada y caracterizada, sino que debe prevenirse, y como "el sistema judicial y la confianza ciudadana en la justicia son esenciales en un Estado democrático de derecho, se requiere prevenir y eliminar los factores que la favorecen o incentivan". ${ }^{36}$ En definitiva: no debe olvidarse que para construir un verdadero sistema acusatorio es indispensable construir un Estado con instituciones políticas consolidadas y debe haber poca corrupción y, además, se debe evitar la politización de los agentes que manejan ese sistema. ${ }^{37}$

\section{Los pronunciamientos de los más altos tribunales.}

Así mismo, mediante los proveídos de la Corte Constitucional diversas disposiciones de la normativa original han sido declaradas inexequibles o exequibles de manera condicionada, esto es, acorde con interpretaciones de ese tribunal que ha desbordado sus funciones para ir más allá de las competencias propias del poder legislativo negativo de que está investido, ${ }^{38}$

\footnotetext{
34 SÁNCHEZ, J. L.: "La reforma judicial y la búsqueda del acceso a la justicia en Colombia”. En: Ratio Juris Vol. 10 N. ${ }^{\circ}$ 21, 2015. Pág. 234.

35 GARCÍA, M. y REVELO, J. E.: Estado alterado. Clientelismo, mafias y debilidad institucional en Colombia. Siglo del Hombre Editores, Bogotá, 2010. Pág. 24.

36 VILLADIEGO Y HERNÁNDEZ, ob.cit. Pág. 368.

37 VERVAELE, ob. cit. Pág. 71.

38 KELSEN, H.: "La garantía jurisdiccional de la Constitución (la justicia constitucional)". En: Anuario Iberoamericano de Justicia Constitucional, No. 15, 2011. Pág. 276; VELÁSQUEZ, F.: Derecho Penal, Parte General, t. I. Editorial Jurídica de Chile, Santiago de Chile, 2009. Pág. 272.
} 
en cuya virtud puede extraer del ordenamiento jurídico aquellas disposiciones que lo contrarían y no invadir las órbitas del legislador mediante el ejercicio de un poder legislativo positivo que, en principio, le está vedado aunque estas potestades suelen ser reivindicadas por los tribunales contemporáneos. ${ }^{39}$ En otras palabras: tal como está concebida la Constitución vigente en su artículo 241, la jurisdicción constitucional solo debería formular exclusiones o señalar los vetos de los textos que se le someten, sin que ella pueda decirle al legislador qué debe agregarle a las leyes para que sean constitucionales pues no es legislador en un sentido positivo.

Otro tanto sucede con las decisiones de la Sala de Casación Penal de la Corte Suprema de Justicia, mediante las cuales -a veces con base en muy discutibles interpretaciones o construcciones que dicen tener ese carácterse le da al cuerpo normativo que contiene el Código de Procedimiento Penal, unos alcances que distan mucho de las construcciones originales diseñadas por sus mentores, de tal manera que más allá de sus funciones estrictamente jurisdiccionales los miembros de ese organismo terminan por invadir la órbita del propio legislador.

Incluso, debe señalarse como la jurisprudencia emitida por los más altos tribunales en materia penal se ha convertido -de hecho- en el derecho vigente desplazando la propia normatividad penal, todo lo cual trastoca el sistema de fuentes del derecho penal diseñado en la Constitución ${ }^{40}$ y que, ahora, de forma solapada, se pretende legitimar en diversas propuestas de acto legislativo; en una de ellas, por ejemplo, se señala que: Los jueces en sus providencias deberán acatar las sentencias de unificación de las altas cortes según lo defina la ley. Todos los casos iguales deberán ser fallados de la misma forma, y la ley establecerá requisitos y procedimientos para unificar la jurisprudencia, incluso entre las altas cortes (Proyecto de Acto Legislativo No. 21, 2018, artículo 12).

Como es obvio, con semejante texto convertido en derecho positivo sería necesario rediseñar por completo el modelo de Estado existente porque con la construcción constitucional actual, la propia de un Estado

39 FIGUERUELO, A.: "La incidencia positiva del tribunal constitucional en el poder legislativo". En: Revista de Estudios Politicos (Nueva Época), No. 81. Págs. 50 y 54.

40 VELÁSQUEZ, F.: "La jurisprudencia como fuente formal del derecho penal. Prevaricato por desconocimiento del precedente jurisprudencial". En: Cuadernos de Derecho Penal No. 9, 2013. Págs. 143 y ss. 
de Derecho Social y Democrático ${ }^{41}$ los jueces no pueden crear derecho a través de sus decisiones así ellos sientan que despachan desde un tribunal inglés vestidos con una túnica de horrible color negro, aunque no munidos de peluca.

\section{La falta de persecución penal, la impunidad y la agobiante conges- tión judicial.}

Cuando se emprendió la reforma se dijo que el cambio producido era una herramienta de lucha contra la impunidad y para el logro de una mejor administración de justicia; sin embargo, eso se quedó en meras declaraciones de buena voluntad porque en el año 2016, cuando asumió el cargo el actual Fiscal General de la Nación éste dijo, en su discurso de posesión, que la impunidad era del 99\% (Noticias RCN, 2016; 2016, Discurso, p. 2), esto es, el mismo índice suministrado por el Departamento Nacional de Planeación en 1991 cuando se echaron las primeras bases constitucionales del modelo actual de administrar justicia penal. También, en 2015, la Corporación Excelencia en la Justicia en su balance de los diez años de vigencia del sistema emite una cifra probable del $99 \%{ }^{42}$

Por ello, pues, no es de extrañar que hace quince años al realizar un informe sobre el país, una reputada organización internacional en materia de derechos humanos se preguntara si en Colombia existía una administración de la justicia...o de la impunidad (Federación Internacional de los Derechos Humanos, 2003). Pero las cifras en esta materia no siempre son concluyentes, como lo evidencia el hecho de que según otras mediciones los cálculos sean menos pesimistas al punto de que se habla de un índice del 66,57, que ponen a nuestro país como el octavo donde mayor impunidad existe, en una muestra que involucra a 69 naciones de todo el orbe. ${ }^{43}$

Aello, añádase: Cuando se propulsó el paquete de reformas introducidas se le vendió al país la idea según la cual el patrón procesal adoptado era un arma para luchar contra la congestión judicial; no obstante, él está

41 DÍAZ, E.: Estado de Derecho y sociedad democrática. Taurus, Madrid, 1983. Págs. 1 y ss.

42 POVEDA et al., ob. cit. Pág. 284.

43 LE CLERCQ, J. A. y RODRÍGUEZ, G. (Coords.): Índice Global de Impunidad 2017 (IGI-2017). Dimensiones de la impunidad global. Fundación Universidad de las Américas, Puebla, 2017. Págs. 9, 38, 44 y 74. 
hoy colapsado porque hay varios millones de actuaciones represadas ${ }^{44}$ que nadie impulsa y es imposible hacerlo por falta de personal y de herramientas. ${ }^{45}$ Para la muestra un botón: En la rendición de cuentas dada por el Fiscal General a la Corte Suprema de Justicia él reconoció que, en promedio, cada fiscal local de Bogotá tiene a despacho 1000 actuaciones, cuando en condiciones normales no debería tener más de doscientas (2018, agosto 30).

Desde luego, con base en desarrollos propios del derecho internacional, ${ }^{46}$ se ha tratado de acudir a ciertos expedientes para tratar de paliar la crisis como sucede con el llamado análisis de contexto en la investigación penal -mecanismo distinto a la priorización que apunta a qué delitos se deben investigar-, en cuya virtud se busca precisar cómo investigar ciertos hechos punibles en atención a su mayor gravedad e importancia, ${ }^{47}$ incluso con apoyo en el Acto Legislativo 1 de 2012 creador del llamado Marco Jurídico para la Paz, en el seno de lo que se ha dado en llamar una justicia transicional. Este tipo de mecanismo termina por desquiciar el sistema procesal penal y tiene graves visos de inconstitucionalidad ${ }^{48}$ por desconocer los derechos fundamentales (debido proceso, presunción de inocencia, juez natural, legalidad, derecho de defensa, publicidad, etc.), amén de que también se muestran sus inconvenientes para la buena marcha de la administración de justicia penal, sobre todo porque da lugar

$44 \quad$ La CEJ a través de POVEDA et al., ob.cit. pág. 284, habla, solo para la Fiscalía General de la Nación, de "una carga total para el año 2014 de 2.607.160 de noticias criminales por atender".

45 POVEDA et al., ob. cit. Pág. 184.

46 FAJARDO, L. A: "Estado del arte en materia de derecho internacional de los derechos humanos y contexto". En: Barbosa, G. y Bernal, C. (Edits.). En: El análisis de contexto en la investigación penal: Crítica del trasplante del derecho internacional al derecho interno. Universidad Externado de Colombia, Bogotá, 2015. Págs. 297 y ss.

$47 \quad$ BARBOSA y PULIDO, 2015. Pág. 26.

48 BERNAL, C.: "Problemas teóricos y de derechos fundamentales del uso del análisis de contexto para la investigación penal en el derecho interno colombiano". En: Barbosa, G. y Bernal, C. (Edits.). En: El análisis de contexto en la investigación penal: Crítica del trasplante del derecho internacional al derecho interno. Universidad Externado de Colombia, Bogotá, 2015. Pág. 104; de otra opinión CORREA, M.: "Análisis de contexto. Estudio desde el derecho constitucional” En: Barbosa, G. y Bernal, C. (Edits.): El análisis de contexto en la investigación penal: Crítica del trasplante del derecho internacional al derecho interno. Universidad Externado de Colombia, Bogotá, 2015. Pág. 268; BARBOSA, G., SUÁREZ, E. y VELASCO, E.: “Aproximación a la noción de "contexto" en derecho penal y procesal penal colombiano". En: Barbosa, G. y Bernal, C. (Edits.): El análisis de contexto en la investigación penal: Crítica del trasplante del derecho internacional al derecho interno. Universidad Externado de Colombia, Bogotá. Págs. 416 y ss., con matizaciones. 
a "problemas conceptuales, normativos y empíricos, con una importancia teórica y práctica manifiesta". ${ }^{49}$

\section{La falta de una policía judicial técnica y unificada; las malas prácti- cas en la recolección e incorporación de evidencias.}

Es más, pese a que en el artículo 250 inc. $4^{\circ}$ num. 8 de la Constitución Nacional se previó que bajo la dirección y conducción del Fiscal General se tendría una policía judicial técnica, científica, unificada, preparada, con recursos para operar a lo largo y ancho del país, ${ }^{50}$ etc., la verdad es que eso tampoco ha ocurrido y el texto contenido en la ley de leyes se quedó en el papel. El cumplimiento del mandato ha sido prorrogado $\mathrm{y}$ es hoy un asunto pendiente de realización que mucho afecta la buena marcha de las investigaciones penales, por lo cual mientras exista una dispersión de actores institucionales con funciones de policía judicial -que ha llevado, incluso, a que por ley esa función se les atribuya hasta a los bomberos- el futuro no es nada halagüeño, máxime si esos organismos obran movidos por celos, rencillas y ánimo de protagonismo. El asunto es todavía más lamentable si se tiene en cuenta que esos entes poseen importantes herramientas para el logro de esas tareas que mucho podrían ayudar a mejor la situación si se unificaran y/o ellos actuaran de manera coordinada; pero, para que operen en forma debida, deben ser controlados para que las investigaciones se puedan edificar a partir de los principios propios de un Estado de Derecho y, ${ }^{51}$ por supuesto, se necesitan leyes modernas que aseguren su funcionamiento correcto. ${ }^{52}$ En ese contexto tampoco las prácticas de recolección e incorporación de los elementos materiales probatorios y de evidencia física son las deseables, ${ }^{53}$ máxime si se tiene en cuenta que con el diseño adoptado el manejo del asunto es

49 BARBOSA Y PULIDO, ob. cit. Pág. 23.

50 Bernal, J., MONTEAlegRe, E. et al.: El Proceso Penal. Fundamentos constitucionales y Teoría general, vol. 1, 6 ed. Universidad Externado de Colombia. Bogotá. Pág. 261.

51 TIJERINO, J. M. F. VELÁSQUEZ: Sistema Penal Acusatorio y nuevos retos. Universidad Sergio Arboleda, Bogotá, 2010. Pág. 89.

52 GÓMEZ, J. L.: "Policía judicial: a la búsqueda de un modelo adecuado para una lucha eficaz contra el crimen”. En: Cuadernos de Derecho Penal, N.. 19, 2018. Pág. 43.

53 Véase, POSADA, R.: "Capítulo 8. El modelo probatorio de la Ley 906 de 2004. Una mirada desde la jurisprudencia de la Corte Suprema de Justicia”. En: Poveda, X. et al.: Balance diez años de funcionamiento del Sistema Penal Acusatorio en Colombia (2004 2014). Análisis de su funcionamiento y propuestas para su mejoramiento. USAID, Bogotá, 2015. Pág. 223. 
sustancialmente distinto; ${ }^{.4}$ y ello suele suceder, entre otras razones, porque el ente investigador se preocupa más por obtener la privación de libertad de los imputados desde la investigación para, con base en aceptaciones de cargos, la aplicación del principio de oportunidad y las negociaciones, lograr la evitación del proceso y de la sentencia. Además, las actuaciones suelen nutrirse de prueba testimonial porque no son muchos los recursos que se tienen a mano para recabar otro tipo de evidencias, sobre todo las de tipo técnico o científico; a lo cual se suman las malas destrezas en la recolección y cadena de custodia de las mismas, o la recurrencia a un formalismo desaforado que también da al traste con las investigaciones.

Por ello, parece imperativa la unificación de todos los organismos que hoy cumplen tareas de policía judicial para que los importantes recursos existentes no se dispersen y se pueda construir un verdadero proceso de partes; sin evidencias, pues, es imposible apuntalar las investigaciones y sin ellas no hay proceso penal posible y tampoco se puede obtener Justicia para que prevalezcan la verdad y el procedimiento adecuado. ${ }^{55}$ Además, se debe tener en cuenta que, para cumplir con dicha función de forma correcta, los hechos no pueden reconstruirse de cualquier manera, "sino sólo recurriendo a medios probatorios cuya aplicación lleve a resultados que se perciban por los ciudadanos como una reconstrucción correcta de lo sucedido". ${ }^{56}$

\section{La presencia de plurales justicias paralelas.}

Del mismo modo, la atribución de competencias a otros organismos diferentes a la jurisdicción ordinaria agarrota el patrón procesal penal adoptado; por eso, al lado de ella se erigen otras que cumplen la misma finalidad: Justicia y Paz, Justicia Especial para la Paz (JEP), penal militar y policial, de menores e indígena. En otras palabras, no es la justicia penal ordinaria la encargada de manejar la mayor parte de los conflictos de índole penal y, ni siquiera, los más graves, porque estos últimos han caído bajo las mallas de una llamada justicia transicional que, para acabar de ajustar, impone penas muy bajas (piénsese en los paramilitares o en los

\footnotetext{
$54 \quad$ SOLÓRZANO, ob. cit. Pág. 393.

55 GÓMEZ, J. L. (Coord.) et al.: Introducción al proceso penal federal de los Estados Unidos de Norteamérica. Tirant lo Blanch, Valencia, 2013. Pág. 347.

56 RAGUÉS, R.: "El Sistema Integral del Derecho Penal: variaciones en torno a una idea". En: Revista Eletrônica de Direito Penal e Política Criminal - UFRGS, Vol. 5, N. ${ }^{\circ}$ 1, 2017. Págs. 1-13. Recuperado de https://seer.ufrgs.br/redppc/article/view/78202/45813. Pág. 6.
} 
delincuentes de Estado) o, sencillamente, no acude a ninguna, como ha sucedido con los miembros de las Farc pese a que cometieron centenares de miles de crímenes de lesa humanidad, ${ }^{57}$ para quienes se crean mecanismos procesales especiales y se expidieron leyes de sometimiento desiguales.

A ello se añade el imperio de la llamada "justicia penal mediática" o "justicia espectáculo" en cuya virtud, de forma grosera, se posibilita a los medios de comunicación masiva apoderarse del conflicto penal ${ }^{58}$ cuando no judicializarlo, ${ }^{59}$ con la finalidad de atraer simpatizantes y potenciales clientes, con el consiguiente desplazamiento de los fiscales y jueces a quienes se arrebatan sus funciones y se les expone al escarnio público cuando no proceden como ellos quieren o, lo que es peor aún, los vuelven sujetos activos de estas prácticas por lo cual muchos de ellos salen a los medios a cumplir tareas que no les corresponden. Inclusive no solo se juzga a quien es procesado sino al titular de la jurisdicción, con la finalidad de obtener una determinada resolución judicial motivada por razones políticas o económicas ${ }^{60}$ a no ser, claro está, que se vuelva un interviniente en el juicio mediático o un asesor que guía al medio de comunicación.

Y ello, obsérvese, es producto de la constante expansión que se observa en los imperios mediáticos, "en la información domesticada $\mathrm{y}$ en la deformación y desinformación que ellos imponen a escala planetaria y, sobre todo, en la estrecha alianza de los mismos con los poderes de gobierno", con la consecutiva imposición de "una información disciplinada, homologada y homologante". ${ }^{61}$ Por supuesto, tan delicado asunto merece "un amplio debate pues comprometen la libertad de expresión, el derecho a la información, el derecho al debido

$57 \quad$ VELÁSQUEZ, F.: "El Nuevo Acuerdo Final y los fines de la pena". En: Revista Eletrônica de Direito Penal e Política Criminal - UFRGS, Vol. 5, N. ${ }^{\circ}$ 1, 2017. Recuperado de https://seer.ufrgs.br/redppc/article/view/78113/45818. Págs. 14 y ss.

58 GARLAND, D.: La cultura del control. Crimen y orden social en la sociedad contemporánea. Gedisa, Barcelona, 2005. Pág. 261; FUENTES, J. L.: Los medios de comunicación y el Derecho Penal. Revista Electrónica de Ciencia Penal y Criminología RECPC 07-16, 2005. Págs. 2 y ss.

59 POVEDA et al., ob. cit. Pág. 293.

60 POSADA, R.: "Los juicios paralelos, el derecho a la honra y al debido proceso penal: ¿quis custodiet custodes?” En: Lecciones de Derecho Penal, Procedimiento Penal y Politica Criminal. Libro homenaje a la Facultad de Derecho de la Universidad Pontificia Bolivariana en su $75^{\circ}$ aniversario. Biblioteca Jurídica Diké-Universidad Pontificia Bolivariana, Medellín, 2012. Págs. 207 y ss.

61 FERRAJOLI, L.: Principia iuris. Teoría del derecho y de la democracia. 2. Teoría de la democracia, traducción de Perfecto Andrés Ibáñez et al. Trotta, Madrid, 2011. Pág. 406. 
proceso, las garantías procesales de víctimas y procesados, así como la presunción de inocencia e inclusive la independencia judicial". ${ }^{62}$ Ese fenómeno, por supuesto, impide la introducción y buena marcha de un modelo acusatorio; y, debe agregarse, no como consuelo de tontos, que ello también sucede en otros lados donde los medios de comunicación también suplantan a los administradores de justicia. ${ }^{63}$ Incluso, de forma preocupante, se observa como esos medios trafican con las evidencias probatorias de esas actuaciones que -a pesar de ser reservadas, no obstante lo cual son suministrados mediante contraprestaciones por parte de servidores públicos-difunden sin control; por eso, al recoger palabras de la doctrina hispana, debe clamarse porque "los medios realicen un tratamiento ponderado y proporcionado de los sucesos criminales" y procuren trascender las reacciones más primarias frente al delito, así como las soluciones más simplistas, por más que ello pueda parecer trasnochado. ${ }^{64} \mathrm{Y}$ esto, recuérdese, es fundamental porque en un Estado de Derecho social y democrático es necesario preservar a toda costa la imparcialidad y la independencia judicial para evitar que el juez termine convertido en un actor político. ${ }^{65}$ En fin, también debe mencionarse otro fenómeno preocupante cual es el de los sistemas punitivos paralelos mediante el cual actores armados de diversas clases (milicianos, paramilitares, bandas criminales, etc.) asumen el control económico, político y poblacional en diversas zonas del territorio, en el campo y sobre todo en las barriadas populares de las ciudades, y le sustraen al Estado la potestad investigadora y sancionadora; así lo enseñan investigaciones puntuales como la realizada en la llamada Comuna Trece de Medellín ${ }^{66}$ en la cual, de forma empírica, se verificó la presencia de diversos actores que al lado de los estatales se disputaban no solo el territorio sino la administración de justicia acorde con sus propios cánones.

\footnotetext{
$62 \quad$ POVEDA et al., ob. cit. Pág. 292.

63 DÍEZ, J. L.: Delitos y penas en España. Catarata, Madrid, 2015. Págs. 69 y ss.; VORMBAUM, Th. \& BOHLANDER, M.: A Modern History of German Criminal Law. Springer, Heidelberg, New York, Dordrecht, London, 2014. Pág. 260.

64 DÍEZ, ob. cit. Pág. 69.

65 ANDRÉS, P.: Tercero en discordia. Trotta, Madrid, 2015. Pág. 215.

66 LONDOÑO, H. L.: Sistemas punitivos y Derechos Humanos. Universidad de Antioquia-Ediciones Jurídicas Andrés Morales, Bogotá, 2016. Págs. 1 y ss.
} 


\section{El fracaso de las formas de evitación del proceso y de la sentencia.}

Así mismo, cuando se emprendió el proceso reformador se dijo que con él se buscaba acelerar las actuaciones al máximo para que solo un porcentaje reducido de los casos fuera a juicio y, con tales miras, se introdujeron por lo menos siete institutos diferentes que dan cabida a los criterios de oportunidad entendida esta expresión en un sentido muy amplio y con los cuales se profundiza la tendencia privatizadora del proceso penal, gracias a una conjunción discutible entre los principios de legalidad $\mathrm{y}$ de oportunidad, ${ }^{67}$ que no responde a una clasificación internacional del principio de oportunidad..$^{68}$ En efecto, aparecen: ${ }^{69}$ el principio de oportunidad en sentido estricto; ${ }^{70}$ la suspensión del procedimiento a prueba; la conciliación en el marco de la justicia restaurativa; la mediación; las negociaciones y a las aceptaciones de cargos.

Estas últimas, téngase en cuenta, también suponen un acortamiento de la actuación procesal y por ende un verdadero procedimiento abreviado de carácter ordinario, con las cuales los reformadores por boca del entonces Fiscal General pretendían pasar de un proceso de años a días porque, gracias a ellas, por lo menos el 50\% de los casos terminarían por la vía anormal sin necesidad de rituar un proceso; incluso se habló de una "verdadera revolución en la justicia del país". ${ }^{71}$ A esos mecanismos, se deben añadir el procedimiento abreviado especial para ciertas delincuencias ${ }^{72}$ y el instituto de la acusación privada por

67 VELÁSQUEZ, F.: La Justicia Penal: Legalidad y Oportunidad. Tirant lo Blanch, Valencia, 2018. Pág. 46.

68 GÓMEZ, J. L.: Los Fundamentos del sistema adversarial de enjuiciamiento criminal (Fortalezas y debilidades del Proceso Penal Acusatorio con Juicio Oral y Público. Su interpretación en América Latina, con especial referencia a Colombia). Ediciones Jurídicas Andrés Morales, Bogotá, 2015. Pág. 399.

69 GUERRERO, O. J.: Fundamentos teórico-constitucionales del nuevo proceso penal, 2 ed. Ediciones Nueva Jurídica, Bogotá, 2007. Págs. 489 y ss.; BERNAL, J., MONTEALEGRE, E. et al.: El Proceso Penal. Estructura y garantías procesales, vol. 2, 6 ed. Universidad Externado de Colombia, Bogotá, 2013a). Págs.859 y ss.

70 Bernal, J., MONTEAlegre, E. et al.: El Proceso Penal. Fundamentos constitucionales y Teoría general, vol. 1, 6 ed. Universidad Externado de Colombia. Bogotá, 2013. Pág. 523 y ss.

71 ARANGO, B. M., PALACIO, J. G. y RIVERA, M. C.: “Justicia: de años a meses". En: El Colombiano, 2004, 13 de junio. Pág. 8A.

72 Sobre todo, las callejeras, para las cuales imperan políticas como las de la tolerancia cero: DE GIORGI, A.: Tolerancia cero. Estrategias y prácticas de la sociedad de control. Editorial Virus, Barcelona, 2005. Págs. 37 y ss.; WACQUANT, L.: Las cárceles de la miseria. Manantial, Buenos Aires, 2000. Pág. 28. 
parte de la víctima y otras autoridades (Ley 1826, 2017) que, después de una reforma constitucional surtida al efecto ${ }^{73}$ le permite a algunos particulares y en relación con esas mismas delincuencias ejercer la acción penal. No obstante, estos institutos no han tenido la demanda esperada como lo reconoció el propio Fiscal General en su informe ante la Corte Suprema de Justicia (2018, agosto 30), pese a que él mismo ordenó montar un show publicitario y mediático con el primer caso en el cual se aplicó el procedimiento abreviado que llevó a dos hermanos a la cárcel por la tentativa de hurto de una teja de zinc (Fiscalía General de la Nación, 2017, agosto 8), quienes fueron condenados en escasas tres semanas pese a que el juez advirtió las "situaciones de marginalidad, ignorancia o pobreza extremas" concurrentes en sus conductas y era de suyo evidente que se les pisoteaban sus garantías, como sucede con este tipo de mecanismos pensados para los sectores para ser aplicados a los sectores más pobres de la población, tal vez porque en el fondo la justicia penal siempre ha considerado a sus «clientes» con base en la clase de procedencia para tratarlos de forma selectiva. ${ }^{74}$ Sin embargo, parece evidente que el remedio para enfrentar la crisis no puede consistir en acabar con el proceso penal para que solo el $5 \%$ de las actuaciones, como sucede en los Estados Unidos ${ }^{75}$ (y en la práctica con el pervertido modelo colombiano que, así esté afincado en el principio de legalidad, posibilita que la persecución penal quede a discreción de la Fiscalía), lleguen a juicio mientras en el $95 \%$ de las mismas aquél no tenga lugar porque las súplicas negociadas o Plea Bargaining se lo tragaron por entero al punto de que, como dice uno de sus críticos, "se obtiene un beneficio a cambio de la renuncia al derecho a ir al juicio". ${ }^{76}$ Eso, se ha dicho con razón, es producto de que el proceso penal es un instituto que ya no le interesa a la clase política pues el fin perseguido por quienes manejan la cosa pública,

$73 \quad$ V VARGAS, R.: "El ejercicio de la acción penal en Colombia. Reflexiones en torno a la reforma al artículo 250 de la Constitución Nacional". En: Cuadernos de Derecho Penal N. ${ }^{\circ}$ 7, 2012. Pág. 59.

74 DE GIORGI, ob.cit. Pág. 66.

75 ISRAEL, J. H., KAMISAR, Y., LAFAVE, W. R. y KING, N. J.: Proceso Penal y Constitución de los Estados Unidos de Norteamérica. Casos destacados del Tribunal Supremo y texto introductorio. Tirant Lo Blanch, Valencia, 2012. Pág. 893.

76 MCCOY, ob. cit. Pág. 71. 
a ojos vistos, es que él no tenga lugar, ${ }^{77}$ en medio de un panorama en el cual se entremezclan la política y la justicia. ${ }^{78}$

\section{La falta de infraestructura y el deficiente recurso humano.}

De igual forma, son notarias las graves falencias en la infraestructura y la mala formación de los servidores encargados de poner a funcionar el modelo adoptado, aunque no puede pretenderse que la capacitación solo se haga con el influjo ideológico del sistema norteamericano desechando los aportes europeos, como pretende una corporación financiada con recursos foráneos la cual no duda en afirmar que aquí "se implementó un sistema particular con unas lógicas especiales, las cuales -con independencia de la ideología de los operadores- deben ser seguidos por ellos respetando el ordenamiento jurídico vigente al cual deben someterse". ${ }^{79}$ Ahora bien, para hacer hincapié en el primer aspecto, pese a los esfuerzos hechos para dignificar los espacios físicos donde se administra justicia sobre todo en las grandes ciudades, también es evidente que en las poblaciones intermedias y pequeñas ello no ha sucedido; además, el ensanchamiento burocrático de la Fiscalía General de la Nación, por ejemplo, por medio del desmesurado crecimiento de direcciones y subdirecciones, deja la constancia de un ámbito de prioridades que no corresponden a las necesidades inmediatas del diseño acogido. Se observa, además, una enorme sobrecarga de funcionarios por medio de la confrontación con esquemas contextuales de investigación, bajo el modelo de rotación de personal según las fases del proceso y, más delicado aún, con una peculiar restricción de la autonomía de los inferiores jerárquicos en la conducción de las actuaciones.

A ello, súmese la falta políticas gerenciales, de buenas prácticas y de gestión que gobiernen la administración de justicia, ${ }^{80}$ para dar paso a la improvisación y a la dilapidación de los pocos recursos existentes; el proceso penal, se acota, como cualquier asunto en el que intervengan las personas "no es ajeno a las posibilidades de perfeccionamiento que estrategias de

GÓMEZ, J. L.: "Tendencias actuales en los sistemas procesales penales europeos e iberoamericanos". En: Ciencias Penales, Revista de la Asociación de Ciencias Penales de Costa Rica, Año 24, No. 29, 2015a). Pág. 38; VELÁSQUEZ, ob. cit. Pág. 9.

78 GÓMEZ, 2015a, ob. cit. Pág. 38; VELÁSQUEZ, F.: Prólogo. Muñoz, O.: Las Raíces Angloamericanas del Sistema Procesal Penal Acusatorio. Universidad Sergio Arboleda-Editorial Jurídica Andrés Morales, Bogotá, 2018a). Pág. XXI.

79 POVEDA et al., ob. cit. Pág. 293.

$80 \quad$ Véase, Ibídem. Pág. 285. 
mejor productividad han brindado, con excelentes resultados, en otros ámbitos de la sociedad humana". ${ }^{81}$ Incluso, el prototipo de reclutamiento de los servidores de la justicia debería ser más riguroso para que, como ha dicho la doctrina hispana, se garantice "que los aspirantes acrediten un conjunto de capacidades y competencias ajustado a las verdaderas necesidades del operar jurisdiccional", para lo cual es necesario introducir

(...) controles de personalidad que solo permitieran progresar en el procedimiento a aquellas personas que mostraran, entre otros rasgos, la coherencia analítica, estabilidad emocional, empatía, y resistencia a la presión que la experiencia cotidiana revela como cualidades de un buen juez o fiscal..$^{82}$

Así las cosas, urge transformar de forma radical el diseño para vincular y promover fiscales, jueces y magistrados, con base en criterios objetivos de mérito y en atención a sus capacidades y a la formación ética, mediante la introducción de verdaderas carreras judicial y fiscal; no es posible, pues, que la administración de justicia penal se convierta en un nido de mediocres e infectos y sea la clase política la encargada de indicar a quienes se vincula o se desvincula en atención a sus apetitos burocráticos. Y esto, nos tememos, es lo que hoy sucede porque según datos de la Corporación Excelencia en la Justicia, en el examen de jueces que se hizo en los inicios de 2015, "de 27.690 personas que se presentaron, solo 1.341 pasaron la prueba, es decir, que sólo un $6,2 \%$ de los funcionarios inscritos podrían tener acceso a las vacantes de la rama judicial". ${ }^{83}$

$\mathrm{Y}$ esto que se predica de los servidores encargados de administrar justicia penal también se debe extender a aquellos funcionarios cuya misión es la de jalonar las políticas públicas en estas precisas materias, como son los presidentes, los altos magistrados, los congresistas, el fiscal general, los ministros de justicia o quienes manejan los temas administrativos propios de este servicio; a título de ejemplo, no parece posible que la ministra de justicia del gobierno actual en una reciente entrevista dada a Colprensa, en la cual se refería al ya citado proyecto de acto legislativo para reformar la justicia, confunda la "detención preventiva" con la "detención domiciliaria"

81 MUÑOZ, O.: Las Raices Angloamericanas del Sistema Procesal Penal Acusatorio. Universidad Sergio Arboleda-Editorial Jurídica Andrés Morales, Bogotá, 2018. Pág. 363.

82 DÍEZ, ob. cit. Pág. 33.

83 POVEDA et al., ob. cit. Pág. 293. 
(Colprensa, 2018, octubre 21), al poner en evidencia su pobre formación académica en estas precisas materias.

\section{La estructura paquidérmica del proceso penal.}

De igual forma, otra de las causas de la inoperancia del diseño procesal penal adoptado ${ }^{84}$ es la ordenación burocrática y en extremo lenta del proceso penal (incluso distinta a la que se desprende de la Constitución Política) que, en franca contravía de lo que debe ser un verdadero proceso de partes que posibilite el libre contradictorio, dotado de agilidad y celeridad, está surcado de partes y de intervinientes que impiden su funcionamiento y le restan agilidad y eficacia; de ahí que la duración de los mismos sea cada vez más grande y la expectativa de que se administre pronta y cumplida justicia ha terminado convertida en una quimera. Las dificultades comienzan cuando en la estructura original se introduce como "interviniente", en realidad una verdadera parte, a la Procuraduría General de la Nación -un ente que no equivale a la Fiscalía de otros países-, que ha terminado convertida en un convidado de piedra que concurre, las más de las veces, a las audiencias a entorpecer el debate procesal y a alargar los procesos cual verdadero "francotirador"; 85 un ente que, recuérdese, no tiene ni puede tener cabida en un sistema de verdad acusatorio. ${ }^{86} \mathrm{~A}$ ese interviniente se suman el fiscal, el imputado y la defensa, el acusador privado (en ciertos casos), entre otros; ${ }^{87}$ adicional a ello, con los desarrollos de la jurisprudencia constitucional también los de la Sala de Casación Penal de la Corte Suprema de Justicia en materia de los derechos de las víctimas que datan de varias décadas, ${ }^{88}$ se introduce a las mismas como una verdadera superparte cuya actuación procesal debería ser delimitada a tiempo para que no termine engulléndose todo el proceso penal, algo muy

84 Bernal, J., MONTEAlegre, E. et al:: El Proceso Penal. Fundamentos constitucionales y Teoría general, vol. 1, 6 ed. Universidad Externado de Colombia. Bogotá, 2013. Pág. 185 y ss.; AVELLA, P. O.: Estructura del Proceso Penal Acusatorio. Imprenta Nacional, Bogotá, 2007. Págs. 77 y ss.; BAYONA et al., ob. cit. Págs. 77 y ss.

85 VARGAS, Á.: La Fiscalía General de la Nación. Desde el "Sueño de la Mariposa". Ibagué: Forum Pacis, 1999. Pág. 100.

86 BAYONA et al., ob. cit. Pág. 92.

87 Véase a GUERRERO, O. J.: Fundamentos teórico-constitucionales del nuevo proceso penal, 2 ed. Ediciones Nueva Jurídica, Bogotá, 2007. Págs. 229 y ss.

88 GUERRERO, O. J.: "A propósito de la participación de la víctima en el proceso penal”. En: F. Velásquez: Sistema Penal Acusatorio y nuevos retos. Universidad Sergio Arboleda, Bogotá, 2010. Págs. 163 y ss. 
diferente a lo que se previó en el diseño original. ${ }^{89}$ No obstante, algunos piensan que el papel de la víctima en nuestro proceso es muy reducido e, ${ }^{90}$ incluso, puede afectar el principio de la igualdad de armas. ${ }^{91} \mathrm{Y}$, no se entienda mal: es muy importante fortalecer el papel de las víctimas y velar por sus derechos, de eso no cabe duda; pero también lo es, que se requiere agilizar el proceso penal para tornarlo en un instrumento que, de verdad, contribuya a administrar justicia penal sin pretender que la única manera de satisfacer los derechos cercenados sea acudir a ese escenario, máxime que en otros países como los Estados Unidos, ${ }^{92}$ Alemania ${ }^{93}$ o Italia,,${ }^{94}$ tomados a veces como prototipo, ello no es así.

Por esa razón, no es extraño que el sistema procesal se desgaste de manera inútil y viva de aplazamiento en aplazamiento porque las audiencias programadas casi nunca se realizan; por ello, el ingenio popular, muy dado a jugar con las palabras y la mordacidad, habla de un "sistema aplazatorio" que no "acusatorio". Además, la forma de rituar los procesos penales muestra cómo, cada día, los funcionarios - por múltiples razones que no es del caso examinar aquí- suelen dejarse llevar por esa tendencia oficinesca, más preocupada por la justicia formal y de espectáculo que por el logro de una justicia material ${ }^{95}$ y si, otrora, un mal endémico eran las represas de papel que devoraban los despachos judiciales, hoy en día un mar de actuaciones sin impulso aplasta el diseño adoptado, todo ello con un saldo lamentable para la administración de Justicia penal y la seguridad jurídica. ${ }^{96}$

89 POVEDA et al., ob. cit. Pág. 291.

90 GÓMEZ, J. L.: Los Fundamentos del sistema adversarial de enjuiciamiento criminal (Fortalezas y debilidades del Proceso Penal Acusatorio con Juicio Oral y Público. Su interpretación en América Latina, con especial referencia a Colombia). Ediciones Jurídicas Andrés Morales, Bogotá, 2015. Pág. 401.

91 SANTOS, M. I.: "La participación de las víctimas y el principio de igualdad de armas”. En: Cuadernos de Derecho Penal, N. ${ }^{\circ} 17,2017$. Págs. 61 y ss.

92 GÓMEZ, ob. cit. Págs. 125 y ss.

93 VOLK, K.: Grundkurs StPO, 7 ed. Verlag C.H. Beck, München, 2010. Págs. 339

y ss.

94 ORLANDI, R.: "Algunas reflexiones sobre la víctima en el proceso penal italiano". En: Cuadernos de Derecho Penal N. ${ }^{\circ} 19,2018$. Págs. 61 y ss.

95 ESCOBAR, J. G.: Conceptos Fiscales. Por los que nacen procesados, 2. ed. Hombre Nuevo Editores-Ediciones Le Monde-Ediciones Desde Abajo, Medellín, 2007.

96 VELÁSQUEZ, F. Presentación. F. Velásquez: Sistema Penal Acusatorio y nuevos retos. Universidad Sergio Arboleda, Bogotá, 2010a). Págs. 7-8. 


\section{Un sistema selectivo y politizado.}

Igualmente, el patrón procesal penal como toda la justicia en nuestro país ${ }^{97}$ es selectivo, esto es, se trata de un diseño colonizado por sectores financieros y agrupaciones que defienden intereses poderosos en desmedro de la persecución de las delincuencias que afectan a otros, con lo cual las herramientas disponibles sirven para combatir las conductas punibles que afectan a esos sectores económicos y no a los demás. También, hay selectividad cuando la persecución solo se dirige sobre ciertas personas acusadas de cometer determinados delitos, en atención a la forma como se manipula a la opinión pública por los medios y la voraz clase política.

De esta manera, pues, la herramienta penal es un instrumento que sirve a quienes detentan el poder de turno para perseguir a sus rivales gracias a vergonzosos capítulos de criminalización de la política; por supuesto, ese fenómeno implica, a su turno, silenciar o mandar a depositar al congelador las actuaciones en las cuales personas afines se ven involucradas. Hay, pues, una evidente desigualdad en la aplicación de la ley procesal penal que tiene visos de discriminación, cuando no de favoritismo, en atención a los intereses que se quieran privilegiar.

A la par, se observa una cada vez más creciente politización de la justicia penal no solo porque la clase política coopta todo el aparato fiscal y judicial mediante una injerencia cada día mayor en la provisión de los cargos y en la emisión de los proveídos judiciales, como de hecho sucede, sino porque también los jueces y fiscales ganan un enorme espacio en la vida política al punto de que saltan de sus despachos a las campañas políticas, como ya sucedió con algún fiscal general (El tiempo, 1997) y se observa, ahora, con el actual funcionario que ejerce esa dignidad cuyas miras políticas son inocultables. Otro tanto cabe decir de los magistrados de la Sala de Casación Penal de la Corte Suprema de Justicia, sobre todo después de que se descubrieran micrófonos implantados por perversos delincuentes en sus salas para grabar sus deliberaciones; ellos, pues, máxime si se tiene en cuenta que poseen facultades electorales para la nominación de parte de la cúpula judicial, "han adquirido un protagonismo insospechado en la definición de los principales problemas institucionales"98 $\mathrm{y}$ son, en realidad,

97 UPRIMNY, R., GARCÍA, M. y RODRÍGUEZ, C.: "Entre el protagonismo y la rutina: Análisis socio jurídico de la justicia en Colombia". En H. Fierro, L. Friedman y R. Pérez (edit.): Culturas jurídicas latinas de Europa y América en tiempos de globalización. Universidad Nacional Autónoma de México, México, 2003. Pág. 297.

$98 \quad$ Ibídem. Pág. 299. 
actores políticos de primer orden. Por eso, con el curso que han tomado las cosas en el país ya no resulta aventurado afirmar que, como en otras latitudes, los jueces y los fiscales tienden a volverse secretarios judiciales de los políticos. ${ }^{99}$

\section{EI desprecio por la Academia.}

En efecto, pese a que en un comienzo buena parte de los estudiosos del derecho procesal y las universidades brindaron un relativo apoyo para la difusión del modelo (conferencias, capacitaciones, concursos, salas de audiencia, etc.), la verdad es que esa efervescencia pasó muy rápido, y hoy cunde el desencanto cuando no el escepticismo. Así las cosas, pronto los actores entusiastas de antes se desentendieron y los procesos académicos se estancaron o volvieron al pasado inquisitivo; es más, muchas cátedras de derecho procesal siguen orientadas al procedimentalismo y no aportan nada al debate teórico, cuando es evidente que se requieren programas agresivos para formar a los nuevos abogados en la lógica propia de un sistema de verdad acusatorio y no en un remedo del mismo, porque es indispensable que ellos "se adapten a los requerimientos teóricos que exige este modelo y al desarrollo de las habilidades prácticas, fundamentales para su funcionamiento". ${ }^{100} \mathrm{Y}$ ello sucede no solo en los cursos de pregrado sino en los de posgrado; incluso, para hablar de estos últimos, se cuentan en los dedos de las manos los programas que, de verdad, tienen un contenido diseñado para difundir la cultura acusatoria. Sigue, pues, sobre el tapete de la discusión la propuesta de un sector de la academia cuando clama:

Desde la academia resulta necesario adoptar con urgencia un cambio de mentalidad, para que se establezca una cultura especial frente al que será el nuevo aparato de justicia criminal en el país. Es indispensable, desde ya, modificar los programas de la asignatura Derecho Procesal Penal o Procedimiento Penal, ajustando las enseñanzas al nuevo modelo y preparando al estudiante para que en el futuro enfrente el reto de un proceso penal estrictamente oral, dinámico, donde se destaque la argumentación judicial como expresión de lo que aprendió en las aulas de cátedra. También, resulta indispensable el cambio de bibliografía o de los textos de consulta, para ahondar en la temática desde el inicio con miras a forjar

$99 \quad$ DÍEZ, ob. cit. Pág. 42.

100 POVEDA et al., ob cit. Pág. 293. 
en el estudiante esa mentalidad moderna que demanda la comprensión del derecho penal y procesal penal de naturaleza constitucional. ${ }^{101}$

Pero no es solo el olvido de quienes se dedican a la faena intelectual por los rudimentos del proceso penal que se busca introducir sino, también, el abandono de los administradores de justicia por los estudios de los eruditos como se evidencia cuando - como ya se muestra en seguida- se estudia el fondo y la forma de las decisiones judiciales, casi siempre mal fundadas, porque se olvida que en un modelo acusatorio el juez está compelido a motivarlas; ${ }^{102}$ y ello no es casual porque se percibe también un irrespeto hacia los expertos que concurren al proceso penal a ilustrar a los servidores de la administración de justicia penal, en medio de un facilismo asustador que ha llevado a un retroceso de proporciones en estas materias porque se aplica a rajatablas la orden dada por algunos capacitadores norteamericanos, quienes dijeron que en el nuevo sistema los debates teóricos estaban condenados a desaparecer porque, ahora, solo importaba el aprender bien las técnicas del juicio oral, cosa que tampoco ha sucedido.

Inclusive y de la mano de lo acabado de expresar, pese a que en el plano teórico los enfoques sustantivo y procesal se complementan como debe suceder en el marco de un derecho penal integrado y no existen las cisuras de otros ordenamientos donde se trata de dos parcelas por completo independientes -recuérdese el caso español-, en la práctica judicial se percibe un inadmisible divorcio entre ambas parcelas. Esas disciplinas, pues, se deben integrar porque, en definitiva,

(...) la misión del proceso penal es contribuir a la consecución del fin último del sistema penal en su conjunto -la preservación de la convivencia y de un determinado modelo de sociedad- por dos vías: aclarando la notitia criminis y garantizando la imposición de la pena y sus efectos para el caso de que se confirme la existencia de delito y la consiguiente necesidad de sanción. ${ }^{103}$

Otro tanto sucede con el secular olvido del derecho constitucional como disciplina llamada a fundamentar la armazón de cualquier sistema

101 PEDRAZA, M. A.: “Constitución política y sistema penal acusatorio". En: Revista del Instituto Colombiano de Derecho Procesal, Vol. 31 N. . 31, 2005. Pág. 152.

102 VARGAS, Á.: El trasfondo jurídico-político del deber de motivar que pesa sobre el juez en el sistema acusatorio" En: F. Velásquez: Sistema Penal Acusatorio y nuevos retos. Universidad Sergio Arboleda, Bogotá, 2010. Págs. 139 y ss.

103 RAGUÉS, R.: "El Sistema Integral del Derecho Penal: variaciones en torno a una idea". En: Revista Eletrônica de Direito Penal e Política Criminal - UFRGS, Vol. 5, N. ${ }^{\circ}$, 2017. Recuperado de https://seer.ufrgs.br/redppc/article/view/78202/45813. Pág. 4. 
acusatorio y sin cuya lectura es imposible armar el proceso penal, ${ }^{104}$ lo que dificulta la tarea de administrar justicia; y ello, tal vez, va de la mano de la falta de formación académica y de la forma como administrar justicia se vuelve un acto rutinario en el cual el ser humano pasa a un segundo plano, como si no fuera evidente que los jueces deben estar por encima del conflicto penal y tener la suficiente autoridad para resolverlo.

Como consecuencia de lo expresado, se observa una evidente falta de calidad de las decisiones judiciales (tanto en la forma como en el contenido) con lo cual se pone de presente la baja preparación académica de los funcionarios en los diversos ámbitos que, se supone, debieran conocer: la dogmática penal y procesal penal, la teoría del derecho constitucional, la teoría de la prueba, la teoría de la interpretación, la criminalística, la criminología y la política criminal, etc., disciplinas hoy indispensables para la prestación de un mejor servicio de justicia penal; ${ }^{105}$ además, esos proveídos suelen ser muy mal escritos y ajenos a los principios que informan una buena técnica jurídica, sin olvidar que muchos de ellos poseen una extensión desmesurada que solo busca mostrar una formación que no se tiene y muy ajena al conflicto que se dirime o se busca resolver. En eso, por supuesto, mucho tiene que ver la ausencia de escuelas de formación para los administradores de justicia y, por ende, de sistemas para hacerlo; ellos quedan, pues librados a su propia suerte y permite afirmar que también la crisis de la justicia penal comienza en las aulas universitarias.

\section{El abuso de la detención preventiva.}

También, es evidente el despotismo observado con el instituto de la detención preventiva que se torna una verdadera pena anticipada ${ }^{106}$ como herencia del sistema inquisitivo. ${ }^{107}$ Por ello la Fiscalía desentendida de las aspiraciones plasmadas tanto en el artículo 250 de la Constitución Política como en el artículo 295 del Código de Procedimiento Penal, solicita la restricción de la libertad de los sometidos a investigación penal como norma general y ello es práctica cotidiana a través de sus delegados, cuando el sistema existente debería hacer un manejo equilibrado de la restricción

\footnotetext{
$104 \quad$ GUERRERO, 2007, ob. cit. Pág. 29.

105 GÓMEZ, J. L.: "Dogmática penal y proceso penal, algunas disfuncionalidades relevantes de la actualidad". En: Cuadernos de Derecho Penal, N. 3, 2010. Págs. 9 y ss. 106 ANDRÉS, ob. cit. Págs. 13 y ss.; Londoño, 2012, p. 10 y ss.; Vélez, 2012, p. 92. 107 FERRAJOLI, L.: Derecho y Razón. Teoría del Garantismo Penal. Trotta, Madrid, 1995. Pág. 776.
} 
de la libertad que se debe disponer solo para los casos más graves, ${ }^{108}$ es más, esa desmedida preocupación por la "cantidad" de órdenes de captura solicitadas y, efectivamente libradas, tiene un grave impacto tanto en la concreción de un patrón democrático de investigación penal como en la transmisión de un mensaje equívoco y lejano de un proyecto acusatorio de proceso penal, según el cual la eficiencia de éste se mide a partir de la capacidad de limitar las garantías fundamentales de los investigados, especialmente de su libertad, y no por la posibilidad de brindar verdaderas garantías a las partes. Con razón, pues, se afirma que

(...) en el sistema procesal colombiano, la excepcionalidad no es talanquera de nada, porque al lado de los "principios" de la libertad y de la presunción de inocencia, concurre una constelación de supuestos y circunstancias, que se acrecientan con cada reforma, con potencialidad para justificar la detención preventiva, al punto que ésta ha devenido en regla. ${ }^{109}$

Es más, se olvida que la función de tal medida cautelar es evitar la frustración de los efectos preventivos de la futura pena, lo cual no se debe confundir con una anticipación de la sanción, pues "es perfectamente posible, por tanto, vincular las medidas cautelares con los efectos de la pena sin vulnerar la presunción de inocencia del sujeto imputado". ${ }^{110}$ Por ello, es evidente que con la detención preventiva se produce entre nosotros un auténtico fraude de etiquetas porque "se proclama formalmente algo, en el deber ser, pero luego ello se desconoce materialmente en el plano del ser". ${ }^{111}$

108 BERNAL, J., MONTEAlegRe, E. et al:: El Proceso Penal. Estructura y garantías procesales, vol. 2, 6 ed. Universidad Externado de Colombia, Bogotá, 2013a). Pág. 520; PEDRAZA, M. A.: La detención preventiva en el sistema acusatorio. 2 ed. Ediciones Jurídicas Andrés Morales, Bogotá, 2010. Pág. 12.

109 LONDOÑO, H. L.: Prólogo. Vélez, L. G.: Otra cara del sistema acusatorio colombiano: Menosprecio de la libertad personal y autoritarismo penal. Imprenta Universidad de Antioquia, Medellín, 2012. Pág. 13.

110 RAGUÉS, ob. cit. Pág. 11.

111 MOLINA, R.: Capítulo 7. "La detención preventiva en la Ley 906 de 2004”. En: Poveda, X. et al: Balance diez años de funcionamiento del Sistema Penal Acusatorio en Colombia (2004 - 2014). Análisis de su funcionamiento y propuestas para su mejoramiento. USAID, Bogotá, 2015.Pág. 211. 


\section{El crecimiento desmedido del instituto de los fueros.}

Incluso, se debe mencionar como otra causa de la grave crisis actual de la administración de justicia penal la forma como ha crecido la institución del fuero, esto es, el fenómeno procesal en cuya virtud se permite alterar las reglas de la competencia objetiva, funcional y territorial, de tal manera que solo un tribunal determinado por la ley es el único competente para enjuiciar a ciertas personas que, incluso, pueden gozar de inmunidad. ${ }^{112}$ Con ello, por supuesto, se crea una absoluta desigualdad en la aplicación de la ley que cobija a un número muy amplio de beneficiados quienes, en la práctica, tienen a su disposición un instituto que tiende a asegurar muchas veces la impunidad por la falta de actividad de los organismos llamados a ejercer el procesamiento de esos funcionarios; piénsese, solo para poner un ejemplo, en lo que sucede con la llamada Comisión de Acusaciones de la Cámara de Representantes.

Por ello, existen privilegios ${ }^{113}$ que amparan al presidente de la República, quien en ejercicio de su cargo solo puede ser juzgado por la Corte Suprema de Justicia, previa acusación efectuada por la Cámara de Representantes ante el Senado; y a altos funcionarios del Estado, que son juzgados por el Senado o por la Corte Suprema de Justicia, según el caso. Así sucede con los congresistas quienes, por mandato del art. 186 de la Carta, solo pueden ser encausados "en forma privativa" por "la Corte Suprema de Justicia, única autoridad que podrá ordenar su detención", aunque en caso de flagrante delito "deberán ser aprehendidos y puestos inmediatamente a disposición de la misma corporación", que ahora dispone de una hechiza doble instancia (Acto Legislativo N. ${ }^{\circ} 01,2018$ ). Tienen, pues, un fuero especial de carácter pleno que los beneficia durante el ejercicio del cargo sin importar si el hecho cometido está o no vinculado con el ejercicio de sus funciones; una vez cesan en sus funciones el privilegio se mantiene para las conductas punibles relacionadas con el ejercicio de las mismas como miembros de la corporación legislativa, aunque con esos criterios juega la jurisprudencia a su antojo.

Adicional a ello, son aforados los miembros de la fuerza pública quienes -sólo cuando cometen delitos en servicio activo y en relación con el mismo servicio- cuyos actos son investigados y fallados por las cortes y tribunales militares con arreglo al Código Penal Militar. Para terminar,

112 VELÁSQUEZ, F.: "Las inmunidades y los privilegios procesales: institutos inconvenientes". En: Cuadernos de Derecho Penal, N. ${ }^{\circ}$ 6, 2011. Pág. 75.

113 Ibídem. Págs. 86 y ss. 
existe el fuero indígena en cuya virtud los ciudadanos aborígenes están sometidos a sus propias autoridades, que están facultadas para administrar justicia dentro de su respectivo ámbito territorial, siempre que no desconozcan la Constitución y la ley. En cualquier caso, pues, el instituto de los fueros debe reformarse y ello supone redistribuir competencias para buscar un juzgamiento de esa clase de personas más objetivo e imparcial, sin someterlo a los vaivenes de la política. ${ }^{114}$

\section{Conclusiones.}

De lo aquí expresado se concluye, entonces, que las dificultades del sistema procesal penal en el medio no solo pasan por los yerros y los vacíos normativos sino que, amén de ello, existe una pluralidad de circunstancias (factores, elementos) que explican desde el punto de vista causal el fenómeno; por eso, es miope pretender -como creen quienes se lucran del proceso legislativo como botín electoral- que el grave estado actual de cosas va a cambiar con improvisadas transformaciones de orden constitucional o legal, como hoy se pretenden llevar a cabo. Es más, en auxilio de esta conclusión acude la Corporación Excelencia en la Justicia cuando señala:

(...) son pocos los ajustes normativos que requiere el sistema para su mejoramiento, pero son muchos más los que se centran en la gestión, en la formación de los actores, en la sensibilización de la ciudadanía, en la adecuada formación de los periodistas y sobre todo en la voluntad política para persistir y no desistir en esta tarea. ${ }^{115}$

El asunto, pues, es de más hondo calado porque si algo está claro es que una reforma judicial no solo debe cambiar la forma en la que se estructura la división de poderes, o reformular las disposiciones constitucionales y legales, sino que ella debe estar orientada hacia una política pública enfocada en "garantizar el derecho fundamental de acceso a la justicia, eliminando las barreras de tipo económico, social, cultural y geográfico que se le presentan a las personas cuando buscan satisfacer sus derechos ante los órganos judiciales". ${ }^{116}$ Así las cosas, no es solo mediante la reforma de los códigos penales ni con el endurecimiento de las penas hasta límites

114 GARCÍA, M. y REVELO, J. E.: Estado alterado. Clientelismo, mafias y debilidad institucional en Colombia. Siglo del Hombre Editores, Bogotá, 2010. Págs. 107 y ss., 214.

115 POVEDA et al., ob. cit. Pág. 294.

116 SÁNCHEZ, J. L.: "La reforma judicial y la búsqueda del acceso a la justicia en Colombia”. En: Ratio Juris Vol. 10 N. ${ }^{\circ} 21,2015$. Pág. 222. 
insospechados -en medio del furor expansionista y autoritario observado por los estudiosos ${ }^{117}$ y por corporaciones dedicadas al seguimiento del modelo acogido-, ${ }^{118}$ no es con el pisoteo de derechos constitucionales y garantías centenarias, como se puede reconducir por senderos de estabilidad y democracia a la Administración de justicia penal patria. Los cambios anhelados deben comenzar por el corroído y descompuesto entramado social, pues sin justicia social no puede haber justicia penal, en un país signado por el atraso, la miseria y el abandono de millones de ciudadanos. Y ello, como es obvio, debe pasar por el fortalecimiento de las instituciones y la construcción de un verdadero Estado en todos los confines del territorio nacional para superar las actuales dos colombias también en materia de la administración de justicia penal y, así, avanzar hacia un derecho penal mínimo, ${ }^{119}$ de garantías, democrático, como debe ser el que impere en el seno de un verdadero Estado de derecho social y democrático.

Sin duda, es en ese contexto que se debe replantear todo el diseño procesal penal existente planeado en su momento para que, ante el agobiante cúmulo de presos sin sentencia, se produjeran condenas sin proceso para lo cual se propuso que las ideas de legalidad y de presunción de inocencia, dos pilares de todo proceso penal liberal propios del Estado de Derecho, fueran reemplazadas por la arbitrariedad y el abuso de poder en el ejercicio de la persecución penal. ${ }^{120}$ Así las cosas, ahora no es posible pretender instaurar un modelo para el cual solo se quieren penas sin juicio y sin culpabilidad; un proceso penal "sin proceso" y, por supuesto, entregado a las "negociaciones" fruto de las coacciones, porque se quiere complacer a algunos detentores de poder autócratas quienes solo aspiran a que se emitan condenas sin motivación alguna.

Es más, debe ser superada la actual realidad en cuya virtud impera un principio de oportunidad -entendida esta expresión en un sentido muy amplio- que, de mano del postulado de legalidad, se erige como el más

117 VORMBAUM \& BOHLANDER, ob. cit. Pág. 261; DÍEZ, ob. cit. Pág. 10; Silva, 2011, p. 11 y ss.

118 POVEDA et al., ob. cit. Págs. 292-293.

119 FERRAJOLI, 1995, ob. cit. Págs. 91 y ss.; BARATTA, A.: Criminología y Sistema Penal. B de F., Montevideo-Buenos Aires, 2004. Págs. 299 y ss.; VELÁSQUEZ, F.: "Corrupción y política criminal". En: L. Greco y A. Martins: Direito penal como critica da pena. Estudos em homenagem a Juarez Tavares por seu $700^{\circ}$ aniversário em 2 de setembro de 2012. Marcial Pons Ediciones Jurídicas y Sociales, Madrid-Barcelona-Buenos Aires-São Paulo, 2012. Pág. 708.

120 VELÁSQUEZ, 2010, ob. cit. Pág. 36. 
trascendente en apariencia, posibilita a los funcionarios solo impulsar las actuaciones que quieren y cuando a bien lo tienen; esto es, rige un principio de oportunidad mucho más avieso que el criticado por muchos durante las pasadas décadas en los Estados Unidos aunque se está bastante lejos de haber hecho un trasplante de instituciones de esa nación a la nuestra ${ }^{121}$ así se advierten en ella raíces angloamericanas. ${ }^{122} \mathrm{De}$ igual forma, es necesario trabajar muy duro para consolidar la credibilidad de todos los ciudadanos en la Fiscalía General de la Nación y, por supuesto, en toda la Administración de Justicia penal. Por ello, son indispensables las iniciativas encaminadas a desburocratizar y, en contra de las prácticas de contratación antecedentes, a la instauración de una verdadera carrera fiscal y judicial porque la actual requiere ser fortalecida. ${ }^{123}$ Ella se debe poner en marcha a la mayor brevedad posible para que, en el marco de un concurso de méritos serio y objetivo, se puedan proveer las plazas con el recurso humano más idóneo. De nada, pues, sirve simular la existencia de la meritocracia para encubrir prebendas, compromisos con los electores y corruptelas, si no se atacan los males de fondo y se dota a la Fiscalía de investigadores y fiscales probos, capaces y comprometidos con la administración de justicia y el Estado de Derecho y, a la par, si no se nombran jueces capaces de cumplir con todos los retos y comprometidos con su tarea judicial.

Asimismo, es necesario sanear las finanzas y propiciar una administración del presupuesto de las entidades encargadas de dispensar el servicio de justicia más transparente; en ese sentido, pues, es prioritaria la construcción de un diseño claro y preciso que permita la viabilidad presupuestal de la Fiscalía y de la Rama Judicial para asegurar que ellas puedan cumplir con sus importantes funciones sin contratiempos de tipo material. Ello, por supuesto, no ha sido posible hasta ahora por los crecientes déficits del presupuesto nacional. ${ }^{124}$ Así las cosas, velar por el fortalecimiento de la Administración de Justicia penal en todos sus frentes es perentorio para construir el Estado de derecho social y democrático que quiere la Constitución y anhelan todos los colombianos; la debida justicia

$121 \quad$ LANGER, M.: "From Legal Transplants to Legal Translations: The Globalization of Plea Bargaining and the Americanization Thesis in Criminal Procedure". En: Harvard International Law Journal, Vol. 45, No. 1, 2004. Pág. 6.

122 MUÑOZ, O.: Las Raices Angloamericanas del Sistema Procesal Penal Acusatorio. Universidad Sergio Arboleda-Editorial Jurídica Andrés Morales, Bogotá, 2018.

123 GARCÍA, M. y REVELO, J. E.: Estado alterado. Clientelismo, mafias y debilidad institucional en Colombia. Siglo del Hombre Editores, Bogotá, 2010. Pág. 216.

124 POVEDA et al., ob. cit. Pág. 288. 
penal es condición para que advenga la verdadera paz, la única que puede posibilitar en el futuro la convivencia de todos en una sociedad armónica, democrática, participativa y justa. Por eso, hoy el papel de la Fiscalía General de la Nación y de la Rama Judicial es fundamental para el logro de esas metas y a ello se deben enderezar todos los esfuerzos; pero, para lograrlo, ella misma tiene que construirse con autonomía, independencia y fortaleza democrática.

En fin, para concluir como se hizo en otro lugar, debe señalarse lo siguiente: las futuras reformas a la legislación procesal penal no deben ser fruto de la imposición, las copias burdas, la moda o del más crudo exhibicionismo, porque la experiencia internacional de los últimos años enseña que, por lo general, esas reproducciones normativas nunca han salido bien; ella, debe ser producto de un largo proceso de maduración que utilice el saldo aprovechable del pasado y, con pie firme, instale los nuevos ordenamientos en el futuro, con un bien logrado equilibrio entre justicia y necesidad, de tal manera que ello no se haga a costa de las garantías, sino que -de cara al nuevo milenio- las profundice. ${ }^{125}$

\section{Bibliografía.}

Acto Legislativo N. ${ }^{\circ} 01$ (2018, enero 18). Por medio del cual se modifican los artículos 186, 234 y 235 de la Constitución Política y se implementan el derecho a la doble instancia y a impugnar la primera sentencia condenatoria. Congreso de la República de Colombia. Diario Oficial No. 50.480 de 18 de enero de 2018. Bogotá: Imprenta Nacional.

ANDRÉS, P.: "Presunción de inocencia y prisión sin condena". En: Cuadernos de derecho judicial, N. ${ }^{\circ}$ 18, 13-46, 1996.

ANDRÉS, P.: Tercero en discordia. Trotta, Madrid, 2015.

ANITUA, G. I.: "La importación de mecanismos consensuales del proceso estadunidense, en las reformas procesales latinoamericanas". En: Revista Brasileira de Direito Processual Penal, Porto Alegre, Vol. 1, No. 1, 2015. Págs. 43-65.

125 VELÁSQUEZ, F.: La Justicia Penal: Legalidad y Oportunidad. Tirant lo Blanch, Valencia, 2018. Pág. 70. 
ARANGO, B. M., PALACIO, J. G. y RIVERA, M. C.: "Justicia: de años a meses”. En: El Colombiano, 2004, 13 de junio. Pág. 8A.

AVELlA, P. O.: Estructura del Proceso Penal Acusatorio. Imprenta Nacional, Bogotá, 2007.

BARATTA, A.: Criminología y Sistema Penal. B de F., MontevideoBuenos Aires, 2004.

BARBOSA, G. y BERNAL, C. (Edits.): El análisis de contexto en la investigación penal: Crítica del trasplante del derecho internacional al derecho interno. Universidad Externado de Colombia, Bogotá, 2015.

BARBOSA, G., SUÁREZ, E. y VELASCO, E.: "Aproximación a la noción de "contexto" en derecho penal y procesal penal colombiano". En: Barbosa, G. y Bernal, C. (Edits.): El análisis de contexto en la investigación penal: Crítica del trasplante del derecho internacional al derecho interno. Universidad Externado de Colombia, Bogotá. Págs. 349-421.

BAYONA. D. M. et al.: "Diagnóstico del sistema penal acusatorio en Colombia”. En: Acta Sociológica, N. ${ }^{\circ}$ 72, enero-abril, 2017. Págs. 71-94.

BERNAL, C.: "Problemas teóricos y de derechos fundamentales del uso del análisis de contexto para la investigación penal en el derecho interno colombiano”. En: Barbosa, G. y Bernal, C. (Edits.). En: El análisis de contexto en la investigación penal: Crítica del trasplante del derecho internacional al derecho interno. Universidad Externado de Colombia, Bogotá, 2015. Págs. 41-134.

BERNAL, J., MONTEALEGRE, E. et al.: El Proceso Penal. Fundamentos constitucionales y Teoría general, vol. 1, 6 ed. Universidad Externado de Colombia. Bogotá, 2013.

BeRnal, J., MONTEALEGRE, E. et al.: El Proceso Penal. Estructura y garantías procesales, vol. 2, 6 ed. Universidad Externado de Colombia, Bogotá, 2013a).

COLPRENSA (2018, octubre 21). Esta debe ser la reforma que se merecen los colombianos. El Colombiano. Recuperado de http://www.elcolombiano. com/colombia/entrevista-a-gloria-maria-borrero-ministra-de-justiciasobre-la-reforma-IY9526930 
CORPORACIÓN EXCELENCIA EN LA JUSTICIA-CEJ: Balance de los primeros cinco años de funcionamiento del Sistema Penal Acusatorio en Colombia. USAID, Bogotá, 2011.

CORREA, M.: “Análisis de contexto. Estudio desde el derecho constitucional” En: Barbosa, G. y Bernal, C. (Edits.): El análisis de contexto en la investigación penal: Crítica del trasplante del derecho internacional al derecho interno. Universidad Externado de Colombia, Bogotá, 2015. Págs. 135-294.

DAMASKA, M. R.: The faces of Justice and State Authority. Yale University Press, New Haven-London, 1986.

DAMASKA, M. R.: Las caras de la Justicia y el poder del Estado. Análisis comparado del proceso legal. Editorial Jurídica de Chile, Santiago de Chile, 2000.

DE GIORGI, A.: Tolerancia cero. Estrategias y prácticas de la sociedad de control. Editorial Virus, Barcelona, 2005.

DÍAZ, E.: Estado de Derecho y sociedad democrática. Taurus, Madrid, 1983.

DÍEZ, J. L.: Delitos y penas en España. Catarata, Madrid, 2015.

El Espectador, Redacción Judicial: El paso a paso que llevó a la extradición a Gustavo Moreno. 2018, mayo 19. Recuperado de https://www. elespectador.com/noticias/judicial/el-paso-paso-que-llevo-la-extradiciongustavo-moreno-articulo-789452

El Tiempo (1997, mayo 8). Renuncia irrevocable del fiscal Valdivieso. Recuperado de https://www.eltiempo.com/archivo/documento/MAM561376

ESCOBAR, J. G.: Conceptos Fiscales. Por los que nacen procesados, 2. ed. Hombre Nuevo Editores-Ediciones Le Monde-Ediciones Desde Abajo, Medellín, 2007.

FAJARDO, L. A: "Estado del arte en materia de derecho internacional de los derechos humanos y contexto". En: Barbosa, G. y Bernal, C. (Edits.). En: El análisis de contexto en la investigación penal: Crítica del trasplante del derecho internacional al derecho interno. Universidad Externado de Colombia, Bogotá, 2015. Págs. 297-348. 
FEDERACIÓN INTERNACIONAL DE LOS DERECHOS HUMANOS: Informe Misión internacional de investigación. Colombia: ¿Administración de la justicia... o de la impunidad? Paris: FDIH. 2003, marzo. Recuperado de https://www.fidh.org/IMG/pdf/co357e.pdf

FERRAJOLI, L.: Derecho y Razón. Teoría del Garantismo Penal. Trotta, Madrid, 1995.

FERRAJOLI, L.: Principia iuris. Teoría del derecho y de la democracia. 1. Teoría del Derecho, trad. P. Andrés Ibáñez et al. Trotta, Madrid, 2011.

FERRAJOLI, L.: Principia iuris. Teoría del derecho y de la democracia. 2. Teoría de la democracia, traducción de Perfecto Andrés Ibáñez et al. Trotta, Madrid, 2011.

FIGUERUELO, A.: "La incidencia positiva del tribunal constitucional en el poder legislativo". En: Revista de Estudios Politicos (Nueva Época), No. 81. Págs. 47-72.

FISCALÍA GENERAL DE LA NACIÓN: Primera sentencia condenatoria bajo Ley de Procedimiento Penal Abreviado. 2017, agosto 8. Recuperado de https://www.fiscalia.gov.co/colombia/seguridad-ciudadana/primerasentencia-condenatoria-bajo-ley-de-procedimiento-penal-abreviado/

Fiscal General rindió cuentas ante la Corte Suprema de Justicia: (2018, agosto 30). Recuperado de https://www.youtube.com/ watch?reload $=9 \& \mathrm{v}=$ bzYWkT0IPpE

FUENTES, J. L.: Los medios de comunicación y el Derecho Penal. En: Revista Electrónica de Ciencia Penal y Criminología RECPC 07-16, 2005. Págs. 1-51. Recuperado de http://criminet.ugr.es/recpc/07/recpc07-16.pdf

GARCÍA, M. y REVELO, J. E.: Estado alterado. Clientelismo, mafias y debilidad institucional en Colombia. Siglo del Hombre Editores, Bogotá, 2010.

GARLAND, D.: La cultura del control. Crimen y orden social en la sociedad contemporánea. Gedisa, Barcelona, 2005.

GÓMEZ, J. L.: "Dogmática penal y proceso penal, algunas disfuncionalidades relevantes de la actualidad". En: Cuadernos de Derecho Penal, N. ${ }^{\circ}$ 3, 2010. Págs. 9-36.

GÓMEZ, J. L. (Coord.) et al.: Introducción al proceso penal federal de los Estados Unidos de Norteamérica. Tirant lo Blanch, Valencia, 2013. 
GÓMEZ, J. L.: Los Fundamentos del sistema adversarial de enjuiciamiento criminal (Fortalezas y debilidades del Proceso Penal Acusatorio con Juicio Oral y Público. Su interpretación en América Latina, con especial referencia a Colombia). Ediciones Jurídicas Andrés Morales, Bogotá, 2015.

GÓMEZ, J. L.: "Tendencias actuales en los sistemas procesales penales europeos e iberoamericanos". En: Ciencias Penales, Revista de la Asociación de Ciencias Penales de Costa Rica, Año 24, No. 29, 2015a). Págs. 34-55.

GÓMEZ, J. L.: "Policía judicial: a la búsqueda de un modelo adecuado para una lucha eficaz contra el crimen". En: Cuadernos de Derecho Penal, N. ${ }^{\circ}$ 19, 2018. Págs. 11-45.

GUERRERO, O. J.: Fundamentos teórico-constitucionales del nuevo proceso penal, 2 ed. Ediciones Nueva Jurídica, Bogotá, 2007.

GUERRERO, O. J.: "A propósito de la participación de la víctima en el proceso penal”. En: F. Velásquez: Sistema Penal Acusatorio y nuevos retos. Universidad Sergio Arboleda, Bogotá, 2010. Págs. 153-177.

INFORME DE PONENCIA PARA PRIMER DEBATE AL PROYECTO DE ACTO LEGISLATIVO: número 21 de 2018 Senado (2018, octubre 9). Gaceta del Congreso año XXVII N. ${ }^{\circ} 817,1-32$.

ISRAEL, J. H., KAMISAR, Y., LAFAVE, W. R. y KING, N. J.: Proceso Penal y Constitución de los Estados Unidos de Norteamérica. Casos destacados del Tribunal Supremo y texto introductorio. Tirant Lo Blanch, Valencia, 2012.

KELSEN, H.: "La garantía jurisdiccional de la Constitución (la justicia constitucional)". En: Anuario Iberoamericano de Justicia Constitucional, No. 15, 2011. Págs. 249-300.

LA ROTA, M. E. y SANTA, S.: Acceso a la justicia de las mujeres. Justicia ordinaria. De Justicia, Bogotá, 2012.

LANGER, M.: "La dicotomía acusatorio-inquisitivo y la importación de mecanismos procesales de la tradición jurídica anglosajona. Algunas reflexiones a partir del procedimiento abreviado". En: J. B. J. Maier y A. Bovino (Comps.): El procedimiento abreviado. Editores del Puerto, Buenos Aires, 2001. Págs. 97-133. 
LANGER, M.: "From Legal Transplants to Legal Translations: The Globalization of Plea Bargaining and the Americanization Thesis in Criminal Procedure". En: Harvard International Law Journal, Vol. 45, No. 1, 2004. Págs. 1-64.

LE CLERCQ, J. A. y RODRÍGUEZ, G. (Coords.): Índice Global de Impunidad 2017 (IGI-2017). Dimensiones de la impunidad global. Fundación Universidad de las Américas, Puebla, 2017.

Ley 906 (2004, agosto 31). Por la cual se expide el Código de Procedimiento Penal. Congreso de la República de Colombia. Diario Oficial No. 45.658 de 1 de septiembre de 2004. Bogotá: Imprenta Nacional.

Ley 1826 (2017, enero 12). Por medio de la cual se establece un procedimiento penal especial abreviado y se regula la figura del acusador privado. Diario Oficial No. 50.114 de 12 de enero de 2017. Bogotá: Imprenta Nacional.

LEWIN, J. E.: Las diez cosas que revela el escándalo de Montealegre. $L a$ Silla Vacía. 2015, septiembre 13. Recuperado de https://asillavacia.com/ historia/montealegre-51534

LONDOÑO, H. L.: Prólogo. Vélez, L. G.: Otra cara del sistema acusatorio colombiano: Menosprecio de la libertad personal y autoritarismo penal. Imprenta Universidad de Antioquia, Medellín, 2012. Págs. 7-24.

LONDOÑO, H. L.: Sistemas punitivos y Derechos Humanos. Universidad de Antioquia-Ediciones Jurídicas Andrés Morales, Bogotá, 2016.

MARTÍNEZ, N. H.: Discurso. 2016, Agosto 1. Recuperado de https:// www.fiscalia.gov.co/colombia/wp-content/uploads/Discurso_Fiscal-1.pdf

MCCOY, C.: "Plea Bargaining as Coercion: The Trial Penalty and Plea Bargaining Reform". En: Criminal Law Quarterly, Vol. 50, No. 1-2, 2005. Págs.67-107.

MOLINA, R.: Capítulo 7. "La detención preventiva en la Ley 906 de 2004". En: Poveda, X. et al.: Balance diez años de funcionamiento del Sistema Penal Acusatorio en Colombia (2004 - 2014). Análisis de su funcionamiento y propuestas para su mejoramiento. USAID, Bogotá, 2015.Págs. 205-211.

MORENO, L. J.: Acceso a la justicia. Academia Colombiana de Jurisprudencia, Bogotá, 2000. 
MUÑOZ, O.: Las Raices Angloamericanas del Sistema Procesal Penal Acusatorio. Universidad Sergio Arboleda-Editorial Jurídica Andrés Morales, Bogotá, 2018.

Noticias RCN (2016, agosto 1). La impunidad en Colombia es del $99 \%$ : Néstor Humberto Martínez. Recuperado de https://noticias.canalrcn.com/ nacional-justicia/impunidad-colombia-del-99-nestor-humberto-martinez.

ORLANDI, R.: "Algunas reflexiones sobre la víctima en el proceso penal italiano”. En: Cuadernos de Derecho Penal. N. ${ }^{\circ} 19,2018$. Págs. 61-68.

OSORIO, L. C. y MORALES, G.: Proceso penal acusatorio. Ensayos y Actas. Ediciones Jurídicas Gustavo Ibáñez, Bogotá, 2004.

PEDRAZA, M. A.: "Constitución política y sistema penal acusatorio". En: Revista del Instituto Colombiano de Derecho Procesal, Vol. 31 N. ${ }^{\circ} 31$, 2005. Págs. 126-152.

PEDRAZA, M. A.: La detención preventiva en el sistema acusatorio. 2 ed. Ediciones Jurídicas Andrés Morales, Bogotá, 2010.

POSADA, R.: "Los juicios paralelos, el derecho a la honra y al debido proceso penal: ¿quis custodiet custodes?” En: Lecciones de Derecho Penal, Procedimiento Penal y Política Criminal. Libro homenaje a la Facultad de Derecho de la Universidad Pontificia Bolivariana en su $75^{\circ}$ aniversario. Biblioteca Jurídica Diké-Universidad Pontificia Bolivariana, Medellín, 2012. Págs. 207-258.

POSADA, R.: "Capítulo 8. El modelo probatorio de la Ley 906 de 2004. Una mirada desde la jurisprudencia de la Corte Suprema de Justicia". En: Poveda, X. et al:: Balance diez años de funcionamiento del Sistema Penal Acusatorio en Colombia (2004 - 2014). Análisis de su funcionamiento y propuestas para su mejoramiento. USAID, Bogotá, 2015. Págs. 213-247.

POVEDA, X. et al.: Balance diez años de funcionamiento del Sistema Penal Acusatorio en Colombia (2004 - 2014). Análisis de su funcionamiento y propuestas para su mejoramiento. USAID, Bogotá, 2015.

RAGUÉS, R.: "El Sistema Integral del Derecho Penal: variaciones en torno a una idea". En: Revista Eletrônica de Direito Penal e Política Criminal UFRGS, Vol. 5, N. ${ }^{\circ}$ 1, 2017. Págs. 1-13. Recuperado de https://seer.ufrgs. $\mathrm{br} / \mathrm{redppc} /$ article/view/78202/45813 
SÁNCHEZ, J. L.: "La reforma judicial y la búsqueda del acceso a la justicia en Colombia”. En: Ratio Juris Vol. 10 N. ${ }^{\circ} 21$, 2015. Págs. 217-242.

SANTOS, M. I.: "La participación de las víctimas y el principio de igualdad de armas". En: Cuadernos de Derecho Penal, N. ${ }^{\circ}$ 17, 2017. Págs. 61-100.

Semana. Fiscal bajo la lupa. La feria de contratos de la Fiscalía ha desconcertado a la opinión pública. ¿Qué está pasando con Eduardo Montealegre? 2015, diciembre 9. Recuperado de https://www.semana. $\mathrm{com} /$ nacion/articulo/fiscalia-de-eduardo-montealegre-en-la-lupa-porcontratos/442192-3

SERJE, C. H.: "Cosmovisión actual de la oralidad en el sistema penal acusatorio desde la perspectiva de la Teoría de la comunicación". En: Cuadernos de Derecho Penal N. ${ }^{\circ}$ 5, 2011. Págs. 66-79.

SILVA, J. M.: La expansión del Derecho Penal. Aspectos de la Política criminal en las sociedades posindustriales, 3 ed. Edisofer-B de F, MadridBuenos Aires-Montevideo, 2011.

SOLÓRZANO, C. R.: Sistema acusatorio y Técnicas del Juicio Oral. Ediciones Nueva Jurídica, Bogotá, 2008.

TIJERINO, J. M. F. VELÁSQUEZ: Sistema Penal Acusatorio y nuevos retos. Universidad Sergio Arboleda, Bogotá, 2010. Págs. 77-91.

UPRIMNY, R., GARCÍA, M. y RODRÍGUEZ, C.: "Entre el protagonismo y la rutina: Análisis socio jurídico de la justicia en Colombia". En H. Fierro, L. Friedman y R. Pérez (edit.): Culturas jurídicas latinas de Europa y América en tiempos de globalización. Universidad Nacional Autónoma de México, México, 2003. Págs. 232-303.

VARGAS, Á.: La Fiscalía General de la Nación. Desde el "Sueño de la Mariposa". Ibagué: Forum Pacis, 1999.

VARGAS, Á.: El trasfondo jurídico-político del deber de motivar que pesa sobre el juez en el sistema acusatorio" En: F. Velásquez: Sistema Penal Acusatorio y nuevos retos. Universidad Sergio Arboleda, Bogotá, 2010. Págs. 139-152.

VARGAS, R.: "El ejercicio de la acción penal en Colombia. Reflexiones en torno a la reforma al artículo 250 de la Constitución Nacional". En: Cuadernos de Derecho Penal N. ${ }^{\circ}$ 7, 2012. Págs. 59-88. 
VELÁSQUEZ, F.: "Colombia: hacia un derecho penal expansionista". En: Revista Berbiquí, N. ${ }^{\circ}$ 29, Colegio de Jueces y Fiscales de Antioquia, Medellín, 2005. Págs. 5-20.

VELÁSQUEZ, F.: Derecho Penal, Parte General, t. I. Editorial Jurídica de Chile, Santiago de Chile, 2009.

VELÁSQUEZ, F.: "La justicia negociada: un ejemplo del peligro de la privatización del proceso penal con el nuevo sistema". En: F. Velásquez: Sistema Penal Acusatorio y nuevos retos. Universidad Sergio Arboleda, Bogotá, 2010. Págs. 13-42.

VELÁSQUEZ, F. Presentación. F. Velásquez: Sistema Penal Acusatorio y nuevos retos. Universidad Sergio Arboleda, Bogotá, 2010a). Págs. 5-12.

VELÁSQUEZ, F.: "Las inmunidades y los privilegios procesales: institutos inconvenientes". En: Cuadernos de Derecho Penal, N. ${ }^{\circ}$ 6, 2011. Págs. 7395.

VELÁSQUEZ, F.: "Corrupción y política criminal”. En: L. Greco y A. Martins: Direito penal como critica da pena. Estudos em homenagem a Juarez Tavares por seu $70{ }^{\circ}$ aniversário em 2 de setembro de 2012. Marcial Pons Ediciones Jurídicas y Sociales, Madrid-Barcelona-Buenos Aires-São Paulo, 2012. Págs. pp. 679-715.

VELÁSQUEZ, F.: "La jurisprudencia como fuente formal del derecho penal. Prevaricato por desconocimiento del precedente jurisprudencial". En: Cuadernos de Derecho Penal No. 9, 2013. Págs. 143-213.

VELÁSQUEZ, F.: "El Nuevo Acuerdo Final y los fines de la pena". En: Revista Eletrônica de Direito Penal e Política Criminal - UFRGS, Vol. 5, N. ${ }^{\circ}$ 1. Págs. 14-29. 2017. Recuperado de https://seer.ufrgs.br/redppc/ article/view/78113/45818

VELÁSQUEZ, F.: La Justicia Penal: Legalidad y Oportunidad. Tirant lo Blanch, Valencia, 2018.

VELÁSQUEZ, F.: Prólogo. Muñoz, O.: Las Raíces Angloamericanas del Sistema Procesal Penal Acusatorio. Universidad Sergio Arboleda-Editorial Jurídica Andrés Morales, Bogotá, 2018a). Págs. XVII-XXVI.

VÉLEZ, L. G.: Otra cara del sistema acusatorio colombiano: Menosprecio de la libertad personal y autoritarismo penal. Imprenta Universidad de Antioquia, Medellín, 2012. 
VERVAELE, J. A. E.: "Bases para la armonización internacional Del proceso penal acusatorio". En: F. Velásquez: Sistema Penal Acusatorio y nuevos retos. Universidad Sergio Arboleda, Bogotá, 2010. Págs. 61-75.

VILLADIEGO, C. y HERNÁNDEZ, J. C.: "Aproximación al análisis de la corrupción en la rama judicial colombiana”. En: L. Villar y D. Álvarez (Eds.): Lucha integral contra la corrupción en Colombia: reflexiones y propuestas. Fedesarrollo, Bogotá, 2018. Págs. 341-373.

VOLK, K.: Grundkurs StPO, 7 ed. Verlag C.H. Beck, München, 2010.

VORMBAUM, Th. \& BOHLANDER, M.: A Modern History of German Criminal Law. Springer, Heidelberg, New York, Dordrecht, London, 2014.

WACQUANT, L.: Las cárceles de la miseria. Manantial, Buenos Aires, 2000 . 
